\title{
DOSTOIEVSKI: A DUPLICIDADE NA ESTRUTURA NARRATIVA DE O DUPLO *
}

\author{
Sigrid Renaux **
}

\section{Introdução}

\section{I.1 Proposição}

Este trabalho pretende examinar e considerar, tendo como embasamento teórico os estudos de Mikhail Bakhtine e Leonid Grossman, a estrutura narrativa de O Duplo, ${ }^{\star \star \star}$ a fim de demonstrar que a "forma" deste romance, que Dostoievski considerou "fracassada", é na realidade um reflexo do conteúdo bifurcado, isto é. a duplicidade ou fragmentaçāo da estrutura corresponderia ao esfacelamento ou bifurcação do conteúdo, através do desciobramento da personalidade da personagem principal. A análise será completada com uma tentativa de encaixar parte do simbolismo da narrativa nāo explorado completamente por Bakhtine e Grossman, no contexto de duplicidade da estrutura, como sugestão para uma futura pesquisa do simbolismo em outras obras de Dostoievski.

Assim. após o levantamento de elementos ao nível da narrativa, tentar-se-á articulação deles, para chegar a uma interpretação da obra que se coadune com o mundo imaginário de Dostoievski, e com a visão polivalente que ele nos deu da sua e da nossa realidade.

\section{I.2. O tema de O Duplo na literatura e sua influência sobre Dostolevski}

o conceito da existência de um "duplo", de uma réplica exata mas geralmente invisível de cada homem, pássaro ou animal, é uma superstição muito antiga e difundida. Na crença popular pensava-se que a alma pudesse sc separar por um certo tempo do corpo. ou acompanhá-lo como sombra.

- Trabalho final apresentado ao professor de Teoria Literária, Dr. Boris Schnaiderman, na disciplina Análise das Estruturas Narrativas dos Contos de Dostoievskí no Curso de Pós-Graduação da Universidade de Săo Paulo e que mereceu concelto A. Junho 1975.

** Sigrid Paula Maria Lange Scherrer Renaux - Mestre em Estudos Anglo-Americanos pela Universidade de São Paulo (1974) com a Dissertaçāo Word, Image and Symbol in H.D.'s Early Nature Poetry. Publica na revista Letras desde 1971. Auxillar de Ensino de Língua e Literatura Inglesa na Universidade Federal do Paraná.

-** Todas as referências a $O$ Duplo na análise foram tiradas da ediçäo brasileira da Obra Completa de Dostoievski, v. 1. Traduçāo de Natália Nunes. Rio, Aguilar, 1963. 
Alóm disso, o aparecimento de nosso "duplo" ou aparição seria sinal de nossa morte próxima. Toda duplicação, segundo Juan Eduardo Cirlot, 1 diz respeito ao binário, à dualidade, à contraposição e equilíbrio ativo de forças, e as imagens duplas simbolizariam esta situação.

O tema do "duplo", de um herói incompleto e de seu duplo catalítico aparece frequientemente na literatura, desde a lenda de Anfitriāo, tratada por Molière e Kleist. através dos românticos E.T.A. Hoffmann em Die Elixdere des Teufels (1815) e E.A. Poe em William Wilson (1839) e The Man of the Crowd (1840), até chegarmos em Dostoievski, no qual o conceito do "duplo" como aīter ego ou contraparte moral é quase que uma constante em sua ficção, a partir de $O$ Duplo (1846): segundo René Wellek, 2 falando do romantismo alemão, foi das melhores obras de Tieck, Brentano, Armim e Hoffmann que se revela a experiência "dass die Welt einem doppelten Boden liesitzt: die Furcht, dass der Mensch finsteren Kraeften, dem Schicksal, dem Zufall, der Dunkelheit eines unbegreiflichen Geheimnisses Ohnmaechtig ausgeljefert ist". E mais recentemente, o tema é tratado simbolicamente em The Secret Sharer (1909) por Joseph Conrad, entre outras obras.

Mas para compreendermos as particularidades de composição em Dostoievski, é necessário, de acordo com Bakhtine, 3 analisarmos a história dos gêneros: na Antigidade Clássica, surgiram gêneros caracterizados pela aliança do "sério-cômico", como o Dialogo Socrático. A Sátira Menipéia, e outros, $\mathrm{cm}$ oposição à epopéia, à tragédia e à história. Estes gêneros novos têm um liame profundo com o folclore do carnaval, o que determina suas caracteristicas fundamentais, colocando a palavra e a imagem numa relação particular com a realidade. A importância do cômico-sério antigo na evolução do futuro romance europeu é que este tem três raizes: a epopéia, a retórica e o carnaval, e é no domínio do sério-cômico que está a origem dos ramos da terceira corrente romanesca, que leva à obra de Dostoievski. O Diálogo Socrático e a Sátira Menipéia sāo os dois gêneros cómico-sérios principais da literatura carnavalizada, e é entre as particularidades da Sátira Menipéia (dadas pelos antigos), que encontramos a experimentação moral e psicoloógica, e a representação de estados psíquicos inabituais: demência, desdobramentos da personalidade, sonhos extravagantes, paixōes loucas, surcidios, etc. Estes destroem a unidade épica c trágica do homem: a personagem cessa de coincidir consigo mesma e esta destruição do acabamento do homem é favorecida por uma atitude dialógica diante de si próprio. Dostoievski, descrevendo o desdobramento, também conserva sempre ao lado da tragédia um ciemento cômico (como em o Duplo).

1 CIRLOT, Juan Eduardo. Diccionário de simbolos. Barcelora, Labos, 1969. p. 188 .

2 WELLEK, René. Konfrontationem. Vergleichende Studien zur Romantik. Frankfurt, Suhrkamp, 1964. p. 24.

3 BaKhtine, Mikhail. La poétique de Dostoievski. Paris, Seuil, 1970. p. 145-237. (Capitulo sobre As particularidadse de composiçăo e gênero nas obras de Dostolevski). 
Bakhtine observa porém que Dostoievski não se inspira direta ou consrientemente na Sátira Menipéia, apesar de acharmos em sua obra todas as particularidade dela; ele apenas pegou a corrente que atravessava sua época, pois a Menipéia está presente năo na memória subjetiva de Dostoievski, mas na memória objetiva do género que ele empregava. Dostoievski inclusive ultrapassa os autores da Menipéia antiga, pois esta ignorava a polifonia, preparando-lhe apenas o caminho, com o Diálogo Socrático.

Continuando sua análise diacrônica, Bakhtine explica como se deu o desenvolvimento posterior da Menipéia na Idade Média, Renascença e Epoca Moderna, sempre renovada por métodos artísticos e correntes literárias diferentes. A carnavalização, então, atingiu Dostoievski como tradição de gênero literário, cuja fonte não literária, o carnaval, pode nem ter sido percebida. A fonte principal da carnavalização para a literatura dos séculos XVII, XVIII e XIX encontrava-se nos autores da Renascença - Boccaccio, Rabelais, Shakespeare, Cervantes - como nos romances picarescos, pois os escritores destas épocas tiraram muito da literatura carnavalizada da Antiguidade e Idade Média. Dostoievski assimilou a carnavalização através destas diversas fontes, mais profundamente porém, através de Balzac. Sand, Hugo, carnavalizaçāo que se traduz por sua ambivalência. De Sterne e Dickens, Dostoievski herdou uma mistura de carnavalizaçäo e sentimentalismo; de Poe e Hoffmann. carnavalização e ideologia romântica. Sofre, além disso. influência de Gogol e Pushkin. Conclui Bakhtine que na obra de Dostoievski a tradição carnavalesca renasce também de modo pessoal, combinada com outros momentos artísticos e servindo a outros fins, ligada como está a tolas as particularidades do romance polifónico.

Já para Grosman, 4 os sósias - junto com os pensadores e sonhadores, jovens ultrajadas. devassos, palhaços voluntários, os puros e os justos - são um dos Leitmotifs da poética de Dostoievski, que definem as figuras e dranas da sociedade humana por ele criada. Repetiçōes temáticas atravessam toda sua obra e seu interesse pelos fenômenos de dupla personalidade, manias e hipnotismo inaugura-se exatamente com Goliádkin, personagem central de 0 Duplo (O Sósla, em Grossman). Por outro lado, como afirma Grossman. o príncipio da iluminação bilateral do tema principal mantém-se domirante em Dostoievski, 5 relacionando-se com os fenomenos do aparecimento Je "sósias" que exercem função importante quanto às idéias, psicologia e composição. E essa bifurcação do tema principal seria um processo artístico aprendido na música. Iembrando o "jogo de dois espelhos face a face. e que enviam um para o outro a mesma imagem".6 E a idéia também do "punctum contra punctum", tão cara a Dostoievski, ou seja, da apresentaçāo

4 GROSSMAN, Leonid. Dostoievski artista. Rio de Janeiro, Civilizaçäo Brasileira, 1967. p. 136-7.

5 Ibid., p. 34.

6 Ibid., p. 32. 
de duas narrativas paralelas, "competindo em tensão de paixōes e intensidade de sofrimenton.7

Se, portanto, as fontes do "duplo" na literatura remontam até a Antiguidade Clássica e Dostoievski as absorveu subjetivamente através de sua vasta leitura de escritores renascentistas e românticos, como afirma Bakhtine por ım lado, e Grossman por outro, que o leitmotif do "duplo" exerce função importante entre as leis básicas de comṕposiçāo Dostoievski, é evidente que deva ser dada a 0 Duplo, obra em que aparece pela primeira vez a bifurcação da consciencia em Dostoievski, uma leitura mais em profundidade, obra básica que é para a compreensão dos grandes romances posteriores: o tema do "sub-solo espiritual" em $\mathbf{O}$ Duplo é

prenúncio daquela decadência que matizou claramente as obras do romancista que envelhecia. Os sofrimentos patológicos das personagens, dominadas pela fragmentação do pensamento, possuídas de uma excitabilidade doentia [...] que perdem o juízo [...] que se inclinam para as alucinaçōes $e$ as idéias fixas $e$, por fim perdem o dom do pensamento lógico e a unidade do discurso. 8

são fenômenos todos magistralmente expressos em Os Demônios e Os Irmăos Karamazov.

Poderíamos ainda mencionar, como complementação, a opiniāo de Arnold Hauser, para quem a psicologia moderna começa com a descrição da discórdia interior da alma, e a expressão mais palpável da discordância do cspirito consigo próprio ć a idéia do "double". Dostoievski, segundo Hauser. descobriu "o princípio capital da psicologia moderna: a ambivalência dos sentimentos e a múltipla natureza de todas as atividades espirituais" e esta desintegração. "que consiste nāo só na incoerência dos elementos da alma humana. mas também no seu constante deslocamento e transformação. revalorização c reinterpretação", são uma consequiência da luta contra o romantismo e da oscilação entre as atitudes romântica e não-romântica. 9

\section{I.3 Histórico de o Duplo:}

O Duplo foi publicado em primeiro de fevereiro de 1846, nos Anais da Pátria, duas semanas após a publicaçāo de Gente Pobre. Segundo Rafael Cansinos Assens, no prólogo da edição espanhola do romance, 10 Dostoievski, no intervalo entre Gente Pobre e O Duplo, havia se inimizado com Bielinski c deixado de ser o jovem gênio que se acreditava. Suas exibiçōes nos salōes literários lhe foram fatais, afastando-lhe todas as simpatias. Dostoievski foge das pessoas, sente-se repelido e se afasta, se perde durante temporadas in-

7 GROSSMAN, p. 31.

8 Ibid., p. 109 .

9 HAỨER, Arnold. História social da literatura e da arte. Sāo Paulo, Mestre Jou, 1972 . v. 2, p. 1025-6.

10 DOSTOIEVSKI, Fiador M. Obras completas. Madrid, Aguilar, 1953. v. 1, p. 207. 
teiras, vai por essas ruas "falando sozinho", como diz sua filha. Nestas condições escreve O Duplo, esta estranha novela, na qual se unem um "sangrantc" realismo psicológico com as fantásticas penumbras dos Contos de Hoffmann.

Se bem que Dostoievski na época acalentasse grandes esperanças em relação a $O$ Duplo, como escrevera ao irmāo ("Goliadkine vai bem encaminhado. Será a minha obra prima" 11) já em dezesseis de novembro de 1845, c seus primeiros capítulos terem produzido extraordinária impressão nos amigos, ele estragou a idéia baudelairiana de que " $\mathrm{cm}$ cada homem há dois postulantes simultâneos, um voltado a Deus e outro para Satanás", segundo Henri Troyat, porque nāo soube dominar a influência de Gogol, do qual ressaltam frases intciras em 0 Duplo ${ }^{12}$. Porisso, mesmo Dostoievski esforçando-se por apagar os vestígios gogolianos, não foi suficiente para salvar o Duplo, que ficou scmpre um romance "à maneira de", embora genial. 13

E a segunda reação ao romance foi a crítica de que se tratava de uma obra "estranha", que nāo correspondia à expectativa criada pela sua primeira obra, não só pelo fato de nāo haver mais romance social (em voga ra Rússia na época) como também pelo fato de Dostoievski aproveitar nesta novela o "desdobramento patológico da personalidade" 14 aplicado à tecnica de ficção literária. Biclinski, o maior crítico russo da época, achava o Duplo

long-winded, lacking in measure, unclear in point of view, and, most important. 'fantastic': [...] The fantastic in our time can have a place only in an insane asylum, and not in our literature; it has a place in the art of the doctor, but not in the art of a poet,

acrescentando que "there should be nothing dark and unclear in art".15 E. como observa Edward Wasiolek a respeito. Bielinski estava certo: a arte deveria ser sempre clara, mas o que é claro para uma época pode nāo o ser para outra. O que Bielinski considerava claro, não era o que Dostoievski considerava claro. 16

Mas de acordo com Leonid Grossman, Dostoievski escutou as críticas de Bielinski sobre os defeitos de forma e falta de medida, que demonstravam quanto seu talento era grande, e ele estava até de acordo com a opiniāo de Bielinski, segundo a qual a forma de 0 Duplo nāo havia logrado e deveria ser refundida. 17 Dostoievski mesmo escreve em 1859 (treze anos após ter escrito ao irmāo como ficara afligido pela idéia de haver iludido a expectativa

11 TROYAT, Henri. A vida de Dostoievski. Lisboa, Estúdios Cor, 1958, p. 94.

12 Ibid., p. 97.

13 Ibid., p. 98.

v. 1. p. 285 .

15 WASIOLEK, Edward. Dostoevskg, the major fiction. Cambrldge, MIT Press, 1964. p. 5.

16 Ibid., p. 5 .

17 GROSSMAN, Lénide. Dostoievski. Moscou, Ed. du Progtès, 1970. p. 66. 
do público e falhado numa obra que podia ser grandiosa, sentindo-se enjoado de Goliádkin. o que torna sua vida infernal e o faz adoecer de desespêro): "Pourquoi perdre une idée remarquable, un type d'une portée sociale immense que j'ai été le premier à découvrir et dont j'ai été l'annonciateur". 18

Segundo Dmitri Chizhevsky, mesmo trinta anos após a publicação de 0 Duplo, Dostoievski tinha uma elevada opiniāo da idéia do conto. Ele admite no Diário de um Escritor, em 1877, que o Duplo foi um fracasso completo, que o conto não saiu. Mas chamou atenção para a idéia do "duplo": "A idéia era muito brilhante e eu nunca propus nada mais sério em literatura". Dostoicvski apcnas, cm 1846, nāo havia achado a forma e dominado a estória, como ele mesmo dissera. Chizhevsky conclui que esta idéia do duplo, que recorre através de suas obras em várias metamorfoses, é uma resposta aos mais profundos problemas espirituais do século XIX e que ela ainda está viva na filosofia de nossa própria época, conduzindo-nos ao verdadeiro centro da visão religiosa e ética de Dostoievski. 19

\section{Análise de 0 Duplo}

\section{II.1 A Duplicidade na estrutura:}

\section{II.1.1 O plano do sonho e da realldade $e$ as "duas narrativas" de Dostolevskd}

Em seu capitulo sobre as Leis de Composiçāo de Dostoievski, Grossman comenta que a lei da epopéia dostoievskiana é

sempre construída sobre dados exatos, isto e, sobre ocorrências da vida real, fatos criminais, acontecimentos políticos e toda espécie de documentos humanos, dos quais se destacam tumultuosos os extraordinários dramas individuais das personagens. Tem-se sempre uma representaçāo de fatos e ocorrências autênticos [...] interrompidos por 'năo sei que outra narrativa', que espanta pela intensidade do sofrimento [...]. Cada narrativa está ligada orgânicamente a outra e completa-a por contraste [...]. Daí provém a ação dramática dupla ou múltipla dos romances de Dostojevski. 20

Estes dois inseparáveis argumentos do romance, esta "iluminaçāo bilateral do tema principal", 21 já mencionada, são básicos para a compreensão de O Duplo, narrativa "contrastante e unitária ao mesmo tempo", na qual "dois temas opostos fundem-se". 22 Em $O$ Duplo, percebemos uma narrativa

18 GROSSMAN, p. 67.

19 CHIZHEVSKY, Dimitrl. The theme of the double in Dostoevsky In: WELLEKK René,- ed. Dostoevsky: a collection of critical essays. Englewood Cliffs, N. J., Prentice Hall, 1962. p. 113.

20 GROSSMAN, Dostoievski artista, p. 31-2.

21 Ibid, p. 34 . Ver também p. 3.

22 Ibld., p. 34. 
bifurcada, refletida como um espelho, nāo só quanto ao tema. como também quanto aos planos, que correm juntos:

Uma ambivalência entre elementos fantásticos e elementos reais, entre sonhar e acordar - é a "situação excepcional" da Menipéia - é estabclecida desde o primeiro parágrafo: Goliádkin acorda às oito, mas continua deitado, "sem fazer um movimento, como alguém que nāo sabe bem se ainda dorme ou se já está acordado, se já está rodeado do mundo real ou se continua a sonhar" ( $p$. 287). As "impressōes habituais" que ele em breve volta a sentir são de que tanto as paredes de seu pequeno quarto cobertas de pó, como a cômoda, as cadeiras, a mesa, $o$ divā e as roupas despidas na véspera o olhavam "como se fossem uns rostos conhecidos", 23 do mesmo modo como o "simpático" maço de notas o encarava com "amabilidade e aprovaçāo" (p. 288).

Por outro lado, um leve prenúncio de um outro argumento se mistura à ambigüidade de planos, enriquecendo-os: a luz cinzenta que entra pela janela embaciada, "insidiosamente" e com "ar soturno" (p. 287) lembra a personagem principal. Goliádkin, de que "não estava efetivamente em nenhum reino fantástico mas em Sāo Petersburgo [...] na Rua Chestilavótchnaia, no quarto andar de uma grande casa, nos seus próprios aposentos". "Insidiosamente", referindo-se à luz cinzenta de outono, parece premunizar algo ameaçador, desconhecido ainda, o que é corroborado pelo "ar soturno". lígubre, da luz: o que poderia realmente ser descrito como uma cena fantástica, de sonho, é a realidade mesquinha de Sāo Petersburgo, ao passo que, para Goliádkin, o "reino fantástico" dos sonhos deveria ser bem diferente daquele ambiente que o cerca como se fosse um rosto conhecido.

A dualidade entre sonho e realidade é novamente estabelecida no final co capítulo IV, quando obrigam Goliádkin a sair da festa de aniversário de Klara Olsúfievna, filha do conselheiro de Estado Bieriendiév, antigo protetor de Goliádkin, e para a qual ele não havia sido convidado:

Sente que subitamente há uma māo que lhe pega no braço, outra que o agarra pelas costas e que ambas o obrigam a sair dali. Nota que o fazem caminhar em direção à porta. Quer falar, fazer alguma coisa... ou antes, já não quer fazer nada. Sorri, apenas maquinalmente. Sente que lhe vestem o casaco, lhe enterram o chapéu quase até os olhos, e vê-se na entrada, no escuro e ao frio, e finalmente, na escada. Tropeça, parece-lhe que cai num abismo. Quer gritar mas verifica que já está no pátio (p. 312).

Esta ambigüidade de planos atinge o climax no capítulo $V$, já com uma crientaçāo para a incipiente loucura de Goliádkin, quando este encontra seu duplo pela primeira vez, no cais do Fontanka, no meio de uma tempestade:

Subitamente, estremece dos pés à cabeça e, inconscientemente, dá dois passos em frente. Olha à sua volta numa grande inquietaçāo,

23 Cf. Noites brancas, em que o heroi também animiza as casas de São Petersburgo, que "corriam a cumprimentá-lo" (p. 642 da Obra completa, v. 1). 
mas nāo vê ninguém. Nem vivalma. Nada avista de extraordinário e. contudo... contudo... pareceu-lhe que algućm estava ali, naquele momento, a scu lado, apoiando-se tal como ele à amurada do cais e, coisa estranha! - que esse alguém se lhe dirigiu e lhe falou com uma voz rápida e sacudida, não muito clara. $\mathbf{E}$ as palavras que proferiu diziam-lhe intimamente respeito. - Que teria sido? Estaria sonhando? - diz, olhando mais uma vez à sua volta (p. 313).

Mas é perto do final do mesmo capítulo que a ambigüidade entre o fantástico e o real, entre sanidade e loucura é levada ao extremo, quando Goliádkin se encontra com seu duplo pela segunda vez:

"Mas afinal que vem a ser isto? - pensou, transtornado - Estarei doido?" Voltou-se e continuou a caminhar, estugando cada vez mais o passo e esforçando-se por não pensar em nada.

Acabou por fechar os olhos. Mas, de súbito, por entre os gemidos do vento e o barulho da tempestade, chegou de novo aos scus ouvidos um ruído de passos próximos. Estremeceu e abriu os olhos. Na sua frente, a uns vinte passos, a silhueta negra dum homem avançava rapidamente [...]. Soltou então um grito de espanto e horror ( $\mathrm{p} .315)$.

Este segundo e terceiro encontros com o duplo na mesma noite transtorr.am tanto Goliádkin que este se pōe a correr, sem perceber por onde passava, pois

sentia-se como alguém que está suspenso sobre um abismo e vê a terra esboroar-se a seus pés. Ainda há pouco a terra tremia. Agora ela se move mais uma vez, fende-se e arrasta-o para a morte. Ele, desgraçado, não tem força nem presença de espírito para recuar, nem sequer mesmo para despregar os olhos do abismo escancarado. Este o atrai e ele se precipita. abreviando por iniciativa própria o momẹto de sua perdiçāo (p. 316).

E, como diz M. Hoffmann, referindo-se ao encontro de Goliádkin com seu duplo. "cet événement invraisemblable est présenté avec la ligne qui sépare la réalité du délire d'un fou". 24 Como um espelho, o real continua se refletindo no fantástico e vice-versa, através dos capítulos subseqüentes: no segundo dia, ao acordar,

todas as extraordinárias aventuras da véspera, as aventuras inverossímeis daquela noite terrivel, surgiram ao mesmo tempo na sua imaginação, em toda a sua crueza. [...] era tudo tāo estranho, tāo incompreensivel, que foda aquela história lhe parecia inacreditável. O senhor Goliádkin estava inclinado a atribuir tudo a um sonho, a um passageiro delírio de imaginação, a um obscurecimento momentâneo do espírito. [...] Por outro lado o senhor Goliádkin sentiā os membros quebrados, a cabeça entontecida, os rins fatigados, e um grande resfriado testemunhava-lhe a veracidade de todos os incidentes do seu passeio noturno (p. 317-318).

24 hofmanN, M. Histoire de la littérature russe. Paris, Payot, 1934. p. 506. 
Mais tarde, ao ir à repartiçäo, Goliádkin encontrava novamente seu duplo que senta à frente de sua própria mesa de trabalho. $O$ fato de seus colcgas não terem percebido nada, deixou-o "perplexo".

Parecia-lhe fora do senso comum. Aquele silêncio extraordinário chegava a assustá-lo. Todavia, o caso era bem claro. Mais: era estranho, horrivel, de enlouquecer. Os pensamentos atravessavam o cérebro do senhor Goliádkin como relámpagos. Parecia-lhe que estavam a assá-lo a fogo lento. Tinha razão. $O$ homem que estava sentado na sua frente era o seu terror, a sua vergonha, o pesadêlo da véspera, era o próprio senhor Goliádkin (p. 320).

E Goliádkin continua suas meditaçōes:

Estarei sonhando ou nāo? [...] E hoje ou ontem? [...] Estarei dormindo ou sonhando? O senhor Goliádkin bcliscou-se para certificar-se de que estava acordado. Nāo, infelizmente não era um sonho. [...] Acaba por duvidar da sua própria existência (p. 320).

Vê-se que a ambiguidade é levada ao próprio plano do tempo, como também do consciente $e$ inconsciente:

Tudo isto, porém, era já demais. O senhor Goliádkin sentia-se no extremo de suas forças. Durante minutos perde os sentidos e a memória. Depois volta a si e dá conta que arrasta a pena sobre o papel, maquinalmente, inconscientemente (p. 321).

A saida do escritório, ao encontrar o duplo, a ambigüídade entre ilusāo e realidade é novamente estabelecida:

De repente o senhor Goliádkin cala-se, para e treme como uma folha ao vento. Fecha os olhos durante um minuto. Entretanto, espera... Se se tivesse enganado! Torna a abrir os olhos. Olha a medo para a direita. Nāo, nāo foi uma ilusão. A seu lado caminha... o outro senhor Goliádkin [...]. (p. 325).

No inf́cio do terceiro dia (cap. VIII), acentua-se o esfacelamento da linha divisoria entre loucura e sanidade, entre fantástico e real: Goliádkin acordou.

lembrou-se do que se passara e franziu as sobrancelhas. Eu, ontem, estava idiota de todo - pensou ele ao levantar-se e olhando a cama do hóspede. Mas qual não foi o seu espanto! Não só o hóspede já nāo estava no quarto, como a cama em que dormia tinha desaperecido! (p. 332).

E a premuniçāo do primeiro capítulo, de que "seria bem desagradável [...] se hoje qualquer coisa corresse mal, se me aparecesse, por exemplo, um furúnculo ou qualquer outra coisa aborrecida" (p. 287) é refletida mais uma vez aqui, ao sentir o Senhor Goliádkin "de modo impreciso, que as coisas não estavam indo bem e que o destino lhe preparava ainda qualquer surpresa desagradável" (p. 382). 
De novo na repartição, não compreende os acontecimentos ao ver o cuplo usurpar seu lugar junto ao chefe; e, ao ser recusado por este a ouvir seus protestos. Goliádkin deixa-se cair numa cadeira e pensa:

Tudo isto é inacreditável! [...] Não é possível ... Eu devo ter sonhado. Fui eu com certeza quem foi ao gabinete do ministro! Fui eu quem julgou que era outra pessoa... Nāo percebo nada! Tudo isto é inverossímil (p. 337).

Já tarde na mesma noite (cap. IX), após haver dormido um pouco, Goliádkin acorda, às duas da manhã e, após haver discutido com seu criado Pietruchka por causa de uma carta a Vakramáiev, Goliádkin volta ao quarto. arrependido de tê-la enviado. Está

sentado no divā. imóvel e apavorado. De repente os olhos fixaram-se num ponto com atenção. Temendo uma ilusão ou uma alucinação, estendeu a mão com uma estranha mistura de esperança e de medo. Não, não era nenhuma ilusāo nem nenhum logro, mas uma carta autentica que lhe era dirigida (p. 349).

Houve então uma intensificação no processo alucinação - realidade, se bem que, um pouco adiante, após ter lido a carta de Vakramáiev,

- senhor Goliádkin ficou durante algum tempo imóvel sobre o divā. Uma nova luz irrompia através do nevoeiro espesso que o rodeava, havia já dois dias. Começava a compreender. Tentou erguer-se, dar volta ao quarto para esclarecer e reunir as idéias dispersas, para dirigir e concentrar o pensamento e para refletir na sua situaçāo a sangue frio. Mas voltou a cair sem forças sobre o divã. (p. 350).

Mantém-se o mesmo "suspense" no início do capítulo $\mathrm{X}$. (quarto dia), com ênfase sobre o plano onirico:

Toda a noite esteve numa semi-sonolência, dando voltas sobre voltas. gemendó e dormindo alguns minutos para acordar logo em seguida. Recordaçōes confusas, pesadêlos horriveis, sensaçōes desagradáveis oprimiam-no de modo angustioso (p. 351).

$E$ as imagens se repetem em sonho: de seu chefe, Andriéi Filipovitch, duro c implacável, de seu duplo com "expressão trocista" no rosto, e de uma festa ná alta roda, em que, primeiro, todos os apreciavam até aparecer o duplo. que fazia mudar a opiniāo dos outros, de modo que, desprezado e enxotado, Goliádkin lança-se à perseguição de seu duplo, só para ver surgir outros duplos em sua volta. Aqui, o sonho é tão real que a linha de separação entre realidade, pesadelo e loucura novamente se esvanece:

Sem poder mais, desesperado, o verdadeiro senhor Goliádkin lança-se contra ele, à sorte. Mas a cada passo que dá. cada vez que o seu pé toca no asfalto do passeio surge debaixo da terra um novo senhor Goliádkin, cada vez mais repugnante e com um ar mais atravido. Todos estes Goliádkini se põem a correr uns atrás dos outros como um bando de patos. Perseguem o senhor Goliádkin 
Senior, que já năo pode respirar. São já tão numerosos que enchem toda a capital. Um guarda diante de tal escândalo, vê-se forçado a agarrá-los pela gola e a conduzi-los ao calabouco mais próximo. Tolhido e gelado de medo, 0 Senhor Golládkin acordou. mas sentiu que a realidade nåo era mais agradável... (p. 353).

Como na cena inicial do conto, a realidade de Sāo Petersburgo é tão desagradável também quanto o reino fantástico dos sonhos. E Goliádkin acorda com um grito.

Mas a realidade é de novo embaralhada quando os sonhos se tornam reais: no mesmo capitulo, à tarde. na repartiçăo, Goliádkin acompanha os movimentos do duplo, que se insinua aos outros, com seu "ar brejeiro, saltitante, mesureiro, sorrindo e caçoando como acontecera na véspera" (p. 359): "Isto era sem tirar nem por o que se passara no sonho do senhor Goliádkin Senior" (p. 350). Do mesmo modo, Andriéi Filipovitch mira Goliádkin "desdenhosamente" (p. 361). quando este lhe quer explicar a perfidia do duplo, e se nega a deixá-lo ver Sua Excelência. como no primeiro sonho. Mais tarde, após ter falado com Anton Antonovitch, o caos em que mergulharà é novamente iluminado por uma nova luz, que era "terrivel" e da qual "emergiam fatos que nunca lhe haviam passado pela cabeça". Recebe carta de Pissarienko, e, "com grande espanto, percebeu então que se encontrava no vestiário dos escritórios, no meio dos funcionários que, tendo terminado o serviço, se dirigiam para a salda". (p. 363).

Resolvido a apanhar o inimigo. Goliádkin se lança em sua perseguiçăo: sua loucura o faz sentir "uma energia desusada" (p. 364).

Apesar disso tinha a impressão de que um simples mosquito [...] teria sido suficiente para, com um simples toque de asas, quebra-lo ao meio. Sentia-se fatigado, exausto. Uma força estranha impelia-o para a frente mas já não tinha ánimo para caminhar e os pés recusavam-se-lhe a andar (p. 364).

Após a cena no café com o duplo, Goliádkin mais uma vez corre atrás de seu inimigo e o apanha, trepando no carro em que este se encontrava. E a realidade da cena é mais uma vez tornada ambivalente, pela presença do elemento onírico:

O carro levava vertiginosamente os dois silenciosos inimigos. 0 senhor Goliádkin mal podia respirar. O caminho era mau, e a cada solavanco ele saltava e corria o risco de quebrar a cabeça. O inimigo não se dava por vencido e procurava precipitá-lo na lama. $E$ ainda por cima o tempo estava horrivel [...]. Não se via nada. $[\ldots]$ o Senhor Goliádkin tinha a impressão de já ter vivido estes instantes. Procurava lembrar-se se não fora na véspera, talvez em sonhos, que sentira algo semelhante. A impressāo que tinha não era de angústia. mas de verdadeira agonia. Apertou-se com força de encontro ao seu adversário e quis gritar. Mas os gritos não lhe saiam dos lábios... Por um instante esqueceu tudo, concluiu que aquela aventura nāo era real, que efa inverossímil e que de nada valia protestar... Tinha chegado a esta conclusāo quando um solavanco maior o chamou à realidade (p. 368). 
Observa-se aqui como nāo apenas os planos do real e do fantástico caminham juntos, como também presente, passado e futuro se misturam, pois a cena da tempestade já vivera antes, e a cena da carruagem será vivida mais uma vez, no final do conto.

A loucura de Goliádkin se acentua, ao procurar Sua Excelência em seu gabinete: não distingue objetos de pessoas. Segue-se outra crise, desta vez "de espanto e de mêdo", no pátio da casa de Olsuf Ivánovitch, ao perceber que perdera a carta que recebera de Klara Olsúfievna: "Vinham-lhe à idéia caras estranhas, lembrava-se de acontecimentos esquecidos havia muito" (p. 380). Sente-se perdido, aniquilado. E, finalmente, seu terceiro sonho se torna um pesadelo na realidade ao ser conduzido para a festa na casa de Olsuf Ivánovitch pelo duplo: E acolhido o "melhor possivel" por Olsuf Ivánovitch, e Goliádkin percebe uma lágrima em seus olhos, como também nos de Klara e Vladimir Siemônovitch.

Pensou que a imperturbável dignidade de Andriéi Filípovitch comovera a todos até às lágrimas. Ou não estaria ele próprio sendo vítima de uma ilusão, pelo muito que havia chorado? Até mesmo naquele momento lágrimas escaldantes lhe corriam ainda pelas faces geladas..." (p. 384).

E a dualidade ilusāo-realidade transforma-se em rcalidade-pesadêlu, ao perceber que

todos lhe davam passagem, o olhavam com uma curiosidade estranha e uma simpatia misteriosa e incompreensivel. [...]. Percebeu vagamente que vinha muita gente atrás dele [...] cochichava-se, falava-se, faziam-se comentários. [...]. Custava-lhe respirar, parecia que abafava. Todos aqueles olhos em cima dele o oprimiam e esmagavam... [...] Depois de súbito, perdeu a noção dos fatos e o sentido das realidades. Logo que voltou a si, deu conta de que se movia no meio dum largo círculo de convidados (p. 385).

A ambivalência final se dá quando, após se ouvir um grito terrível, ensurdecedor, "repetido como um eco de mau agouro" pelos que o rodeavam. Goliádkin c conduzido pelo médico Krestian Rutenspitz a uma carruagem, que o leva a um manicómio:

O senhor Goliádkin sentia uma dor estranha no coraçāo; o sanguo parecia ferver-lhe na cabeça. que estalava. Sentia-se abafar, teria querido desabotoar-se; pór o peito ao léu, cobrí-lo de neve, inundá-lo de água fria. Acabou por perder os sentidos... Quando voltou a si [...] julgou que ia desmaiar de medo. Dois olhos, brilhantes como duas brasas, olhavam-no na penumbra do carro e refletiam uma alegria diabólica e de mau presságio.

Nāo era Krestian Ivanovitch... Quem seria entāo? Era ele? Ele? Sim, era de fato Krestian Ivanovitch. nāo o antigo mas um outro Krestian Ivanovitch, que agora the parecia terrivel (p. 388).

O plano do real e do fantástico novamente correm paralelos, pois nāo distinguimos se Goliádkin ao se referir a "Ele", está pensando no duplo ou 
no novo Krestian Ivanovitch. E a cena final acaba com Goliádkin repetindo "Ai dele! Já há muito pressentia que, mais tarde ou mais cedo, isto havia de acontecer..." ambiguizando mais uma vez os planos do presente, passado e futuro.

Concluindo, vimos como a superposição dos dois planos da narrativa, o fántástico e o real, o sonho ou a loucura e o acordar, a sanidade, é um dos clementos de composição básicos nesta obra, atravessando-a do começo ao fim. Como diz o próprio Dostoievski, “... aquilo que a maioria chama de quase fantástico e excepcional, constitui às vezes para mim a própria essência do real". 25 Esta experimentação psicológica, com representação de estados psíqicos incomuns, é incluida por Bakhtine, como já mencionado, como uma das características da Menipéia e ela é uma das causas da bifurcação da narrativa. Isto é confirmado por Rafael Cansinos Assens no prólogo da cdiçāo espanhola de 0 Duplo, em que Dostoievski,

muy acertadamente, desde el punto de vista literário, mantiene la ambiguedad del proceso novelesco entre lo objetivo-real y lo idcal-subjetivo, con lo que se cnriquece doblemente el interés del relato. El drama puede desarrolar-se en la realidad cxterior o en le cerebro perturbado del señor Golidkin. y de ambas maneras puede considerar-lo el lector. sin que por eso resulte menos impressionante, menos trágicamente bufo. 26

Grossman apresenta esta lei de composição de Dostoievski, das duas narrativas.

como uma horizontal do entrecho em desenvolvimento, interceptada pelas verticais dos episódios tumultuosos, que erguem a ação para a altura, e que parecem transportá-la para um novo plano, onde a linha do argumento, paralela à primeira, em breve também se precipitará para o alto, em virtude da explosão de uma nova ocorrência incomum. 27

Esta linha de composição em degraus elevaria então o entrecho "até a sua conclusão definitiva, na catástrofe final e na catarse concludente". Aplicando esta linha de composiçāo em degraus a 0 Duplo, teríamos o seguinte modelo:

\section{1.० dia}

cap. I - Goliádkin finge não ser ele

cap. II - Goliádkin confessa ao médico ter inimigos

cap. III - Goliádkin é caçoado pelos colegas, não é recebido na festa de Olsuf Iv.

cap. IV - Goliádkin vai à festa, comete tolices, é expulso.

25 GROSSMAN, Dostoievski artista, p. 62.

26 DOSTOIEVSKI, Obras completas, v. 1, p. 207.

27 GROSSMAN, Dostoicvski artista, p. 36 . 
cap. V - Goliádkin "aniquilado" encontra seu duplo na ponte, em meio à tempestade.

\section{2. dia}

cap. VI - Goliádkin e duplo na repartição, duplo o acompanha até sua casa

cap. VII - Duplo dorme lá. após travarem amizade.

\section{3. dia}

cap. VIII - Duplo apossa-se dos papéis de Goliádkin na repartição, ridiculariza-o perante os colegas.

cap. IX - Goliádkin e duplo no restaurante, este lhe prega uma peça. Carta de Vakramáiev "aparece" à frente de Goliádkin.

\section{4. $\mathrm{dia}$}

cap. $\mathbf{X}$ - Goliádkin tem pesadelos. E ridicularizado na repartição e desprezado pelo chefe.

cap. XI - Ridicularizado pelo duplo no restaurante, Goliádkin o perseguc. lutam na carruagem. Lê carta de Klara, despeja remédio no chāo, na taberna.

cap. XII - Pietruchka o abandona. Goliádkin expulso da casa do ministro

cap. XIII - Goliádkin aguarda no pátio de Olsuf Iv. é levado à festa pelo duplo, e de lá ao manicômio, pelo médico.

\section{II.1.2 A topografia cênlca como projeçăo da personagem e local de confitito}

\section{Para Massaud Moisés,}

a geografia do conto deve estar diretamente relacionada com o drama que lhe serve de motivo: a paisagem vale como uma espécie de projeçāo das personagens ou o local ideal para o conflito [...]; nẵo é pano de fundo, mas algo como personagem inerte, interiorizada e possuidora de força dramática. 28

Em 0 Duplo, o espaço exerce ambas as funçōes, pois, se o quarto de Goliádkin E um "prolongamento" de sua própria personalidade, se a tempestade na noite de seu encontro com o duplo parece contribuir para o seu próprio aniquilamento, todos os outros cenários servem de local para conflitos internos - na mente de Goliádkin - e externos - com as outras personagens,

28 MOISES, Massaud. Guia prático de análise literária. Săo Paulo, Cultrix, 1970. p. 108 . 
Dostoicvski cscolhe como panorama da ação, como também em Gente Pobre, a Petersburgo de meados do século XIX. E o fundo realista, sobre o qual, como já mencionado, ele constrói a fantástica luta interior-de sua personagem principal. Mas esta visão panorâmica de São Petersburgo, que além de ser o ambiente real em que vive o pequeno funcionário de uma repartição pública, é também um "símbolo vivo, repassado de imenso sentido interior c de desenvolvimento incessante". 29 esta visão é fragmentada numa série de "close-ups" que nos dão a trajetória do herói, contribuindo também para seu desvendamento psicológico. São os seguintes os locais principais do conto, e sua função:

\section{1) $\mathrm{O}$ quarto de Golladkin:}

Tanto o ambiente e até os objetos que cercam Goliádkin projetam o aspecto gasto, decaido. "usado", da personagem: o pó das paredes e a luz cinzenta que entra pela janela embaciada, retratam a "realidade mesquinha" (p. 287) que o cerca, assim como o espelho no qual Goliádkin se olha ao soir da cama reflete "seu rosto ensonado, de olhos semicerrados, um tanto gasto [...] daqueles que passam despercebidos", fazendo-nos associar os viclros embaciados da janela com seu rosto de olhos semicerrados, que não ceixam entrar luz, como também o seu rosto gasto com o quarto cheio de pó. A cor verde sujo das paredes aparece também nas ramagens de seu divã turco e em seus próprios trajes: a :carteira verde já usada" em que guarda um "maço de notas verdes" (p. 288). E o samovar, do mesmo modo como os móveis e o maço de notas, é animizado, murmurando a Goliádkin "com o calor de sua estranha fala: - 'Estou pronto. meu amigo, tire-me daqui..."'.

Além dessa funçāo, o quarto também serve como local para conflito, pois no pequeno corīedor que dava para a entrada da casa, Goliádkin dá com "o criado rodeado de outra criadagem e de espectadores de acaso. Pietruchka falava, os outros escutavam. Teriam sido as palavras de Pietruchka ou esta assembléia imprevista que desagradaram ao senhor Goliádkin? (p. 288). Segundo Grossman, uma das caracteristicas de composiçāo de Dostoievski são os conclaves, as cenas tumultuosas, as reuniōes incomuns com complicaçōes imprevistas, 30 que elevam a narrativa, projetando ao mesmo tempo a desconfiança de Goliádkin. sua mania de perseguição em relação aos outros.

Mais tarde, após seu encontro com o duplo, quando este o precede aos seus aposentos, o quarto torna-se mais uma vez local de conflito, pois o duplo "usurpa" seus aposentos e sua cama, ao sentar-se nela e o cumprimentar: Goliádkin pára no meio do quarto, "como se um raio o tivesse fulminado" (p. 317).

23 GROSSMAN, Dostoievski artista, p. 157.

30 Ibid., p. 38 . 
Entretanto, na noite seguinte, o quarto serve até como local de unificação de Goliádkin e seu duplo, pois, após o convite de Goliádkin, o duplo o acompanha à sua casa e jantam juntos, trocam confidências, bebem, e fumam. E aqui também que surge o "manuscrito alheio",31 apontamentos da personagem, que, segundo Grossman, interrompem a ação aprofundando a caracterização da personagem. Aqui, é o duplo que escreve uma "quadra muito sentimental" a Goliádkin:

Se tu viesses a olvidar-me,

Eu jamais te olvidaria!

Venha lá o que vier,

Deves também recordar-me! (p. 330)

Esta quadra, com scu duplo sentido de amizade e traição, ilumina não só a personalidade do duplo, pérfido e insinuante, como também lança luz sobre o futuro: Goliádkin nunca poderá deixar de recordá-lo, pois é por causa do duplo que ele acabará num manioômio.

O quarto de Goliádkin, além das duas funçōes mencionadas por M. Moisés, também serve de local de cena carnavalesca entre ambos, pois, ao cair c chapéu de Goliádkin ao chão, ambos se precipitam para o apanhar, após r. que duplo "limpa-lhe o pó com todo o cuidado" (p. 326). Mais tarde, Goliádkin convida o duplo a dormir em sua casa, numa "cama improvisada sobre duas cadeiras grandes" (p. 330). O "travestissement" do duplo, que parece vestir "roupas alheias", pois são grandes demais, é completado pelos seus gestos "carnavalescos": puxa o colete, encolhe-se, parece querer sumir. O quarto, portanto, torna-se o lugar do "contato livre e familiar" 32 entre ambos.

Por outro lado, efeitos de "iluminação rembrandtiana, da luta de luz e sombra" 33 sāo ainda conseguidos quando Goliádkin ilumina com uma vela c hóspede que dormia em seu quarto, concentrando assim, toda a parca iluminação no rosto de seu duplo enquanto o resto do aposento permanece ro escuro. Esta mesma iluminação lúgubre é explorada mais uma vez quando Goliádkin volta, na terceira noite, exausto e confuso pela humilhação que havia sofrido na repartiçāo: "a vela ardia tristemente, a luz dançava nas paredes" ( $p .346$ ), refletindo seu estado de espírito. Outra cena carnavalesca se segue a csta, pois Goliádkin, ao acordar no meio da noite, vai ao quarto de Pietruchka (como extensāo de seu próprio quarto) acordá-lo, e a mesma iluminação que acima exercia funçāo reveladora do drama de Goliádkin, é aqui usada com finalidade cómica:

Nesse momento a vela apagou-se. Passaram dez minutos antes que o senhor Goliádkin encontrasse outra vela e a acendesse. Durante estes dez minutos Pietruchka voltou a adormecer... 'Patifc, camalha, maroto...' - gritava o senhor Goliádkin sacudindo-o. -

31 BAKHTINE, p. 176.

32 Ibid, p. 170.

33 GROSSMAN, Dostoievski artísta, p. 159. 
'Levantas-te ou nāo? Acordas ou nāo?' Ao cabo de uma meia hora de esforços. o senhor Goliádkin conseguiu acordá-lo e arrasta-lo para fora... Mas Pietruchka estava a cair de bêbado e mal se tinha nas pernas". (p. 347).

Os aposentos de Goliádkin servem ainda de local de crise entre Goliádkin c Pictruchka, quando este lhe diz que vai "para casa de gente de juizo, de pessoas que não têm embrulhadas nem duplos..." (p. 348) - Goliádkin é "destronizado" como patrāo pelo criado - como também são cenário da descoberta e do envio de mais "manuscritos alheios": a carta que Goliádkin subitamente vê em seu quarto, c que, como já mencionado, intensifica o processo alucinação-realidade, e uma outra, projetando a mania de perseguição 3. as reaçōes patológicas de Goliádkin, abrindo ao mesmo tempo novas persde Goliádkin e respondida à altura. Ambas novamente esclarecem a situnçāo pectivas sobre a vida passada do herói, que desconheciamos.

Finalmente, o quarto é local, como já visto acima, de três horriveis pesadelos que Goliádkin tem, na mesma noite, em conseqüência de todos estes acontecimentos. No primciro é desprezado pelo chefe, na repartiçāo, no segundo ć caçoado pelo duplo em público e no terceiro é humilhado e "destrorizado" pelo duplo numa festa, até que, enxotado, corre à rua, lugar onde aparecem, a cada passo que dá, novos duplos... (pp. 351-3). E o "manuscrito alheio", a carta que envia ao duplo ao acordar, somente demonstra o paroxismo, a extrema intensidade a que chegaram os sentimentos de Goliádkin. cm relação ao duplo, ao escrever: "Ou o senhor ou eu. Ambos não pode ser. [...] estou à sua disposição para um duelo à pistola" (p. 354).

As duas últimas cenas passadas em sua casa já fazem parte praticamente do dénouement do conto, pois o mandato que recebe do chefe, demitindo-o, Pietruchka indo embora e Goliádkin ouvindo a discussāo das vizinhas embaixo, com Pietruchka, nada mais sāo do que reflexos de cenas que já aconteceram ou que Goliádkin já previra que iriam acontecer.

\section{2) A repartiçāo}

A repartiçāo também exerce a dupla funçāo de local de conflito e de cenas carnavalescas: segundo Bakhtine, o carnaval exerceu influência determinante sobre a literatura e os diferentes gêneros, 34 e a carnavalização, isto é, a transposição do carnaval na literatura através da Menipéia é um dos conceitos-chave na obra de Dostoievski, como mencionado acima. Se no quarto de Goliádkin tivemos já um esboço de carnavalização, é realmente na repartição que esta característica toma vulto, pois o "lugar" do desenrolar do carnaval scria a praça pública mas também as casas, onde teriam lugar o contato livre e familiar e também as en- e destronizaçōes públicas. Esta ambivalência do local de ação, no caso da repartição em que trabalha Goliádkin, inicia-se quando Goliádkin. sentado junto ao chefe Anton Antônovitch, evitando provocações com colegas, tenta descobrir algo de novo no rosto deles:

34 BAKHTINE, p. 169. 
"Procura uma ligação estrcita entre os acontecimentos da vćspera e as atitudes de hoje", deseja uma solução, mesmo "desfavorável" (p. 319). "A porta da sala vizinha" rangeu de levc, timidamente, como a anunciar que ia dar passagern a uma personagem insignificante. $\mathrm{E}$ o duplo aparece à sua mesa, senta-se em frente de Goliádkin, enquanto este enterra "a cabeça nos papéis". Esta nova crise eleva a ação, pois este acontecimento inesperado faz Goliádkin sentir-se no extremo de suas forças, espantando-se com o fato de ninguém parecer ter dado pela semelhança entre ambos.

No dia seguinte, dá novamente com o duplo "num vão duma porta" na ıepartição. Desta vez, a repartição é o local da usurpação dos papéis que Goliádkin deveria entregar ao chefe Andriéi Filipovitch, pelo duplo:

fingindo querer tirar um borrão numa folha, o duplo agarrou o papel que o chefe pedira mas em vez de o rapar com o canivete, enrolou-o, meteu-o debaixo do braço e em duas passadas estava junto de Andriei Filípovitch, que nāo dera por nada.

O senhor Goliádkin ficou pregado no lugar, com o canivete na mão, como se se preparasse para rapar alguma coisa (p. 336).

Precipita-se em direçāo ao gabinete do diretor, mas é tarde, sua "destronização" perante o Ministro já havia ocorrido.

A "maldita cornucópia", a açāo de velocidade desabalada, a alternância estonteadora de acontecimentos fulminantes que entram em acordo e se despencam sobre a personagem - mais uma das características de composiSão de Dostoievski, segundo Grossman 35 - começa a se derramar sobre Goliádkin: além de o duplo ter recebido as honras pelo trabalho e Andriéi Filípovitch não querer ouvir Goliádkin, seu sósia conversa com todos e desafia Goliádkin com palavras, caretas e piparotes - gestos carnavalescos - para gaúdio dos colegas que os rodeiam. Goliádkin acaba por vir a si e compreende que "está pcrdido. desonrado, que deu cabo de sua reputação, que se cleixou escarnecer e insultar em público" (p. 338), enquanto o duplo desaparece "no compartimento vizinho".

E a crise, a cena tumultuosa, a reunião incomum com complicações imprevistas, é o princípio de construção do "simplório ludibriado" de que se vale Dostoievski, 36 nesta cena que é ao mesmo tempo entronizante e carnavalizante para o duplo, e destronizante e de crise para Goliádkin.

Na saída da repartiçāo há outro momento decisivo: Goliádkin agarra o auplo no último degrau da escada, mas este consegue escapar, pegando um "drójki" e desaparecendo de sua vista. Goliádkin então "apóia-se tremendo de encontro a um poste de luz", aniquilado, pois "tudo parecia agora definitivamente perdido" (p. 340).

No quarto dia, dá-se novo conclave na repartição: à hora da salda, os funcionários mais novos rodeiam Goliádkin. fechando-lhe a saida. Então, como no sonho que tivera, um "acontecimento inesperado" dá cabo dele: apa-

35 GROSSMAN, Dostoievski artista, p. 42.

36 Ibid., p. 39. 
rece o duplo, abrançando a todos e por fim estendendo a mão a Goliádkin. Temos então outra cena de carnavalização, pois o duplo retira com insolência sua mão da de Goliádkin, cospe nela e limpa-a com o lenço. Após isso. ntaca Goliádkin de "nosso Faublas russo", enquanto os funcionários se mostram indignados e descontentes com Goliádkin. Este decide falar ao chefe, mas, como no sonho. Andriei Filipovitch recusa e Goliádkin é desprezado peJa terceira vez. Além disso, é acusado por Anton Antônovitch, scu velho amigo. Assim. a cornucópia continua vertendo seus infortúnios sobre o pobre Goliádkin: crises, destronização, humilhação e entronização de seu sósia.

Entretanto, não só a repartição como até a entrada serve de local de conflito e projeção da personagem: Goliádkin ama os lugares escondidos, de onde pode obscrvar os outros sem scr observado. Ao ver o escriturário Ostúfiev entrar no vestíbulo, cle também se introduz na entrada, chamando-o "com um ar misterioso para um canto retirado, atrás de um grande fogāo de ferro" (p. 354). Assim escondidos, interpcla-o sobre as novidades de "dentro" da repartição. Um pouco depois, pela fresta da "muralha" que o escondia. Goliádkin mete o nariz, mas ao ouvir passos descendo a escada se "esconde atrás do fogão" (p. 357): é o duplo passando. que sobe rapidamente a escada de novo, "fingindo não o ver" (p. 358).

\section{3) O salāo de festas na casa do conselhelro de Estado Blertendiélev:}

A festa, como um procedimento para reunir pessoas de diferentes níveis snciais (aqui, os chefes e os funcionários mais categorizados), assim como sua programação que não obedece a nenhum esquema rígido (improvisa-se um pequeno baile, após o jantar), é um procedimento típico dos contos de Dostoievski, como em Uma Anedota Ordinária. A Arvore de Natal e um Casamento, e outros. E novamente o "conclave" para Grossman e a "utopia social" para Bakhtine, em que Dostoievski foge da realidade "mesquinha" (para Goliádkin) de Sāo Petersburgo, apresentando um mundo de fantasja. em que todos estão nivelados como convidados do conselheiro Bieriendiéev (antigo protetor de Goliảdkin), cuja filha, Klara, fazia anos.

Nada falta a mais este elemento da Menipéia: a descrição da festa faz deste acontecimento um "festim real" (p. 304) mais do que um jantar, pois "o esplendor, o luxo, a etiqueta davam ao cenário um ar babilônico". Não falta a abundância a esta festa, em que a taça de vinho "parece cheia com um nectar divino" (p. 305), em que há brindes, discursos, instantes solenes; todos se comunicam neste espetáculo sincrético, pois anfitriāo e chefes confraternizam com os convidados subalternos, há felicitaçōes, beijos, risos, abraços, a amabilidade das senhoras é extrema, as esposas dos funcionários "parecem mais fadas do que mulheres" e eles próprios estāo "transformados agora em brilhantes homens de salão" (p. 306). Fala-se francês, o russo é usado só para cumprimentos e apenas na sala de fumar se permitem "frases familiares". A aniversariante é "a rainha da festa" e as "conveniências" são esquecidas - Anton Antônovitch "cacarejou como um galo c recitou versos 
muito engraçados" (p. 306) e a aniversariante o beija após seu discurso clerruba-se tudo ditado pela desigualdade social.

Este mundo utópico da festa poderia ser contraposto, como o nível da fantasia, ao quarto de Goliádkin. o mundo da realidade mesquinha, o que é corroborado por toda a descriçāo da festa acima. E Goliádkin se encontra "qquase lá" (p. 307), numa situaçāo "a mais estranha possível":

está no patamar da escada de serviço da casa de Olsuf Ivánovitch: [...] metido num cantinho frio e sombrio, escondido por um armário enorme e por um biombo velho, no meio dos restos e da louça suja. Enquanto espera, observa os acontecimentos como um espectador indiferente.

durante quase três horas. Este espaço oferece novo contraste com o brilho e o esplendor da festa, projetando assim a situação lastimável em que Goliádkin se encontra em relaçāo aos convidados da festa.

Mas do vestíbulo onde se encontrava, Goliádkin resolve entrar para a copa, e de lá para a sala de jantar e salāo de baile. E a festa de aniversário, que servira de local de "utopia social", transforma-se em local de conclave para o escândalo e crise, e também de comicidade, o que abala a estrutura do conto, como diz Grossmann: é o conclave e a cena carnavalesca, juntos. Goliádkin passa de uma para a outra sala e "cai como uma bomba na sala de baile" (p. 308): como só tem olhos para Klara Olsúfievna, ele nāo dá conta de nada e avança, dando encontrōes, pisando no vestido de uma senhora, empurrando um criado, dando cotoveladas, até se encontrar diante de Klara. Quer "meter-se num buraco", cada vez que está numa situação crítica (assim como se encafua "no lugar mais escondido da carruagem" quando scus colegas de repartiçāo o vêem em semelhante coche, passeando na Avenida Litiéinaia (p. 290): sua presença torna-se motivo de escândalo na festa, para a qual nāo havia sido convidado. Todos se agrupam em sua volta, riem e cochicham, mas Goliádkin consegue chegar a um canto, onde permanece. A conduta excêntrica de Goliádkin transforma-se em elemento cômico e a festa torna-se lugar de transformaçōes bruscas, de destronizaçōes: Goliádkin é desdenhado por todos; o criado tenta afastá-lo com um recado, mas nāo consegue. Os convidados o olham, se bem que "tudo se passa entre pessoas bem educadas" (p. 311), mas Goliádkin sente que se trata de um "momento decisivo", que é hora de "confundir os seus inimigos": por alguns instantes sente-se entronizado pelas palavras solenes que pronuncia, mas o instante solene é novamente diminuido, há uma reviravolta na situaçāo, quando a orquestra entoa uma polca. Goliádkin é esqueciclo c, quando tenta dançar com Klara, cambaleia e nova cena cômica se sc'gue: "Forma-se novo círculo à sua volta (destronização). Duas senhoras de idade que ele, ao recuar, quase atirou ao chão. soltam gritinhos e lamentaçōes. A confusão é terrivel" (p. 311-312). Goliádkin é agarrado pelas costas e obrigado a sair dali. E uma cena de "travestissement", outro dos ritos 
secundários do carnaval, 37 que se segue: "Sente que the vestem o casaco, the enterram o chapću quase até aos olhos, e vê-se na entrada, no escuro e ao frio, e finalmente, na escada" (p. 312). E o fim de seu sonho de ascensão social, caracterizado mais uma vez pelo contraste da festa brilhante e alegre com o corredor escuro e frio em que é lançado, mas também do ambirnte "onde estivera enclausurado" com a rua, onde encontra "ar e liberdade".

A festa entāo, serviria, como local de crise e de escândalo, para elevar a ação para o clímax, que é o encontro de Goliádkin com seu duplo, na ponte.

Este mesmo salāo de Olsuf Ivánovitch também serve de local para a catástrofe conclusiva, para o encontro de todas as personagens, que, para Grossman, "lembra os tutti num coral, isto é, a participação de todas as vozes". 38 E também a "maldita cornucópia" em açāo, a série estonteante final dos acontecimentos fulminantes que acaba de se despencar sobre Goliádkin: as salas estão apinhadas de convidados, todos querem levá-lo na direção de Olsuf Ivánovitch. Goliádkin, sem visão nítida das coisas, abre caminho entre os convidados, até ser quase empurrado ao compartimento vizinho. Todos que o rodeavam esperavam um "acontecimento extraordinário", até que alguém chega, todos se levantam e Goliádkin e seu duplo sāo colocados um em frente do outro: o clímax final do romance, a última destronização de Goliádkin, quando o duplo, "com um sorriso mau nos lábios" e "uma intençāo mıalévola" no olhar (p. 386) lhe dá um beijo "sonoro e pérfido". Após esta "confrontaçāo" - mais uma das caracteristicas da Menipéia 39 - esta apresentação das últimas palavras e açōes decisivas do homem, dá-se outro acontecimento inesperado: a porta do salão se abre e aparece o doutor Krestian Rutenspitz, que leva Goliádkin consigo, enquanto seu sósia "avança saltitante, tira uma vela das māos dum criado, caminha para a frente, iluminando o senhor Goliádkin e Krestian Ivanovitch"... (p. 386) Os convidados se precipitam atrás de Goliádkin e do médico e até na escadaria. "brilhantemente iluminada", estava uma multidāo de pessoas, enquanto Olsuf Ivanovitch "presidia à cena do patamar de cima [...]. Parecia que todos aguardavam qualquer coisa" (p. 387). A destronização é completada com a entrada de Goliádkin na carruagem, ajudado por Krestian Ivánovitch e Andriei Filípovitch, encuanto "o duplo, covarde como de costume, empurrou-o por detrás" - a tragédia é novamente abaixada ao nível da comédia, pelos gestos carnavalescos do duplo.

A casa do ministro: como o havia sido a casa de Olsuf Ivánovitch, também o gabinete do ministro é local de cenas de destronização e conclave. Goliádkin, após ter sido primeiro recusado pelo criado, entra no gabinete do ministro, pedindo-lhe demissão e que o defenda do inimigo. Mas, ao ver o ministro virar a cabeça. "a vergonha e o desespero apossaram-se dele"

37 BAKHTINE, p. 174.

38 GROSSMAN, Dostoievski artisla, p. 44.

39 BAKHTINE. p. 161. 
(p. 376). E o conclave se encerra com um "torneio oral", 40 processo sutil $\mathrm{em}$ que as frases centrais do material vocabular parecem fulminar $o$ inimigo no momento do combate: aqui, no gabinete do ministro, após a entrada de Krestian Rutenspitz e do duplo, que "aparece no meio da porta, que o senhor Goliádkin supusera ser um espelho, como já acontecera uma outra vez" (p. 376), o her6́i se dirige ao ministro, acusando o duplo: "E um homem vulgar e corrompido. Excelência - disse ele. Estava transtornado, morto de medo; contudo, corajosamente, apontava para seu infame sósia que anCava de volta do ministro" (p. 377). E o duplo, após um movimento geral, avança e o interpela: "Dè-me licença que lhe pergunte [...] diante de quem $\therefore$ que o senhor julga que está falando? Diante de quem está o senhor? Em casa de quem?" E Goliádkin é empurrado "brandamente", com o seu "covarde gêmeo" à frente, indicando-Ihe o caminho. E na antecámara, outra cena de "travestissement" ocorre, abaixando novamente a tragicidade do acontecimento ao nível do cómico:

O sobretudo, o sobretudo... do meu melhor amigo! o sobretudo do meu melhor amigo! - disse o infame com voz de falsete. Arrancou o sobretudo das mãos dum criado e - brincadeira disparatada! - meteu-lho pela cabeça abaixo.

Enquanto procurava libertar-se, o senhor Goliádkin ouviu distintamente os dois criados rindo (p. 377).

E, assim como a entrada da repartiçăo havia servido de local de espera, de esconderijo para observar os outros, e a entrada da casa de Olsuf Ivánovitch também exerceu função semelhante, o pátio da casa de Ivánovitch é local da espera da "catástrofe conclusiva" vista acima, como Grossman chama a culminaçāo do drama que se funde com o epilogo: Goliádkin. encharcado e fraco, tenta sentar-se "num cepo grosso que estava junto de um montão de cavacos". (p. 378), procurando "um canto cómodo onde pudesse escōnder-se à vontade". Não era o mesmo "cantinho de entrara da casa" do princípio do conto. "entre um armário e um velho biombo, no meio do lixo, dos restos e da louça suja de cozinha" (p. 378-9). Aguardando o desenrolar dos acontecimentos, após pagar o cocheiro que esperava por ele há tanto tempo, Goliádkin também corre embora, mas depois decide voltar atrás. Outra vez atrás da pilha de madeira, percebe "uma estranha agitação" na casa:

Todos procuravam olhar para o pátio. Escondido atrás da pilha de lenha, o senhor Goliádkin, interessado, olhava por sua vez este movimento. Estendia o pescoço para um e outro lado. tendo o cuidado de não sair da sombra projetada pela pilha de lenha (p. 383).

Quando percebeu que estavam à procura dele, e que "a sombra o tinha traído e não o cobria já por completo" quis esconder-se "entre os cavacos, em qualquer buraco", mas era impossível. Chamam-no e o duplo vem correndo, "aos pulinhos", conduzi-lo escada acima.

40 GROSSMAN, Dostoievski artieła, p. 52. 


\section{4) 0 cals do Fontanika e a ponte Ismallov, na noite de tempestade:}

Após sua destronizaçāo na festa de Klara Olsúfievna, Goliádkin "começa a andar sempre em frente, sem nunca mais se voltar" (p. 312). Chega ao cais do Fontanka, perto da ponte Ismaílov, "fugindo aos seus inimigos e perseguidores". Todo o cenário parece se crguer contra ele, como o fizeram seus "inimigos" na festa:

Estava uma noite medonha, uma noite de novembro úmida e brumosa, toda de chuva e de neve [...]. O vento soprava nas ruas desertas, erguia acima das cadeias da ponte a água negra do Fontanka, batia nos candeeiros do cais que respondiam a estes assobios com um ranger agudo e lamentoso. [...] Chovia e nevava ao mesmo tempo. Empurrada pelo vento. a água caía em jorros quase horizontais [...]. Batia e chicoteava o rosto do infeliz senhor Goliádkin, como se fossem agulhas e alfinetes aos milhares. [...] $\mathrm{Pa}$ recia que a esta hora, e com um tempo assim, ninguém poderia andar nas ruas. [...] A neve, a chuva, toda a agitação difícil de exprimir, da tempestade prestes a desencadear-se no céu de novembro de São Petersburgo, perseguem o senhor Goliádkin, já tão acabrunhado com os seus próprios desgostos. [...] Todos os elementos se unem contra o senhor Goliádkin como se estivessem de acordo com os seus inimigos, a fim de que tivesse um dia e uma noite de amargura. (p. 312-313).

A função da noite de tempestade no cenário serviria pois, para revelar a aniquilação física do herói pelas forças da natureza o perseguindo, assim como ele já havia sido aniquilado mentalmente, pelo escândalo na festa. Ele quer outra vez "esconder-se de si próprio". "reduzir-se a pó: tudo lhe é indiferente, está "tão desesperado, tāo atormentado, tão perturbado, tāo fatigado e fraco que esquece tudo, a ponte Ismallov e a Rua Chestilavótchraia e até o presente" (p. 313).

E neste cenário adverso de uma noite de tempestade, na amurada do cais do Fontanka, que o acontecimento que eleva ao máximo a narrativa tem lugar: - encontro de Goliádkin com o duplo, como consequéncia de sua personalidade desdobrada patológicamente, acrescido do seu desejo de "morrer". Segundo. Edward Wasiolek, "he purges himself by [...] a ritualistic giving of his distasteful traits to another". 41

No primeiro encontro, Goliádkin tem a impressão de que "alguém estava ali, naquele momento, a seu lado, apoiando-se tal como ele à amurada do cais [...]" (p. 313), falando-lhe com "voz rápida e sacudida, não muito clara". A neve aumenta, não se distingue nada, so se ouve o lúgubre chiar dos candeeiros e a canção do vento, "mais lúgubre" ainda. Goliádkin pỏe-se novamente a caminho, desembaraça-se da neve na sua roupa, mas

"só não pode desembaraçar-se dos seus estranhos sentimentos". O estampido de um canhão avisa que as águas do Nieva tinham subido, e Goliádkin avista à sua frente "um transeunte, talvez algum retardatário, que vem na sua direçăo" (p. 314).

11 WASIOLEK, p. 9. 
O transeunte se aproxima e Goliádkin cruza com ele, mas

de repente, parou assombrado como se um raio the tivesse caido em cima; depois voltou-se bruscamente para trás, para olhar pelas costas a tal pessoa que acabava de passar por ele. Voltou-se como puxado por um cordāo, tal como um catavento que gira em torno de um eixo ...

E neste movimento cruzado que se opera entre os dois passantes que se daria a transmutaçāo do Goliádkin I em Goliádkin II, num ato que não cleixa de estar ligado à carnavalizaçāo, pela sua ambigüidade: é o nascimento c a morte. a en- e destronização - "o herói morre nega-se) em cada um de seus duplos para se renovar (se purificar e se ultrapassar)". 42 Depois, o transeunte desaparece "na espessura da neve... [..] pelo passeio do Fontanka" (p. 315).

Mas Goliádkin, mais uma vez, "entre os gemidos do vento c o barulho da tempestade", ouve passos e avista a sua frente "a silhueta negra dum homem" que avançava rapidamente. O efeito de luz e sombra de que falava Grossman é aqui aproveîlado ao máximo, pois Goliádkin, ao se lançar em sua perseguiçāo fá-lo deter-se a uns dez passos dele. "sob a luz do candeeiro nais próximo, que o iluminava completamente", na escura noite de tempestade. Após seu afastamento. Goliádkin tremendo. "acabou por se sentar, suspirando, numa das beiras do passeio" sugerindo assim uma posição de inferioridade em relaçāo ao duplo. Depois, pōe-se a correr por diversas ruas, que lhe parecem um "labirinto" até que avista novamente o desconhecido, que "seguia o mesmo caminho e corria à sua frente, alguns passos mais adiante... Vai agora já na Rua Chestilavótchnaia" (p. 316), "pára diante da casa de Goliádkin e após tocar a campaínha, desapareceu sob o teto abobadado". E a destronizaçāo que se completa, com o duplo penetrando nos aposentos de Goliádkin. 13

\section{5) As escadas:}

Grossman comenta como a arquitetura também fornecia a Dostoievski "objetos concretos para um desvendamento psicológico semelhante da imagem objeto" e como

a escada aparece como um símbolo do sobressalto, da pcrplexidade e dos pressentimentos sombrios, como campo de açăo de cenas penosas e de sofrimentos tremendos. Goliádkin passa duas horas parado na entrada de serviço dos Bieriendiéiev, depois é expulso do baile para a frígida escadaria de gala, de onde se despenha, conforme lhe parece. num abismo. 44

42 BAKHTINE, p. 176.

43 Cf. p. 15.

44 GROSSMAN, Dostoicvski artista, p. 157. 
Mas a escada também projeta a personalidade de Goliádkin, sua dificuldade $\mathrm{m}$ relacionar-se còm os outros, pois, ao procurar o médico no começo do romance, Goliádkin "sobe a escada procurando conter as pulsações do coração, que the batia sempre com muita força quando subia qualquer outra escada que nāo fosse a sua" (p. 281). Opostamente, ao descer as escadas à saida do consultório, "sorria e esfregava alegremente as māos" (p. 298).

Ao ir à casa de Olsúf Ivánovitch, Goliádkin "sai do coche, pálido, alheado, sobe os degraus do patamar, tira o chapću, compōe a roupa maquinalmente, e com uma leve tremura nos joelhos, começa a subir a escada" (p. 307): ela seria o obstáculo à sua ascensão social e por isso mesmo, "campo de ação de cenas penosas", pois Goliádkin é afastado pelo criado para dar passagem a dois convidados, entre os quais seu chefe, Andriéi Filípovitch. Novamente embaixo, Goliádkin encara seu chefe, ao alto, que "parecia prestes a cair sobre ele". Mas Goliádkin sobe de novo a escada "de um pulo" (p. 303) e o chefe corre a fechar a porta atrás de si. Após descer correndo a escada. Goliádkin quer "meter-se num buraco, esconder-se como um rato, a si e a carruagem" (p. 304). E a conseqüência de sua "infraçāo". é a primeira destronização, um preâmbulo à destronização que se seguirá, ao penetrar realmente na festa.

\section{6) Restaurante:}

O restaurante "muito conhecido da Perspectiva Niévski, mas de que ele mal tinha ouvido falar", serve também para projetar a ânsia de ascensão social de Goliádkin (p. 300), sua vaidade, pois, ao encontrar lá dois de seus colegas de repartição, fica pcrturbado, deseja manter "uma certa distância" (p. 300) deles e por fim assume um "ar importante ao se despedir deles.

Mais tarde, quando nāo há mais necessidade de aparentar, Goliádkin vai a um bar de aparência modesta, numa ruazinha estreita, para pedir um jantar.

E, após o duplo haver usurpado seus papéis na repartição, o mesmo restaurante onde tinha estado a descansar enquanto esperava pela hora do jantar de Olsuf Ivánovitch é cenário de autro escándalo: após haver comido um bolo, na hora de pagar o empregado lhe diz que comera onze. Espantado, Goliádkin acaba pagando, mas de repente compreende o enigma. Na porta "que Goliádkin supunha ser um espelho" em sua frente, estava o duplo, comendo o décimo bolo. E novamente o elemento cômico ao lado da tragédia c esta nova crise leva Goliádkin a se humilhar perante os outros fregueses: "O senhor Goliádkin estava perplexo. Parecia obra de feitiçaria! Entretanto o vendedor csperava. Já havia gente em volta do senhor Goliádkin.

Tirou um rublo do bolso. Estava vermelho como um camarāo (p. 343).

Após haver sido "destronizado" pelo duplo na repartiçāo, Goliádkin consegue a custo convencê-lo a explicarem-se mutuamente a situação. Dirigem-se a um café deserto, onde, após fingir amizade em relação a Goliádkin. o 
Cuplo despede-se, apertando-lhe "desdenhosamente" dois dedos e repetindo "a jntolerável graçola daquela manhā". "Já tinha metido no bolso o lenço com que limpara os dedos, quando o senhor Goliádkin número um se pôs a perseguir na sala vizinha o seu figadal e covarde inimigo". (p. 367). E a alemã, vendo fugir os dois clientes, "pós-se a gritar e a tocar a campainha com toda a força". (p. 368).

Esta combinação de cenas penosas com gestos carnavalescos, tão evidente acima, é mais uma vez projetada, no cenário. no mesmo dia, quando Goliádkịn vai a uma taberna: lê a carta que Klara Olsúfievna lhe enviara, colocando-se sob sua proteçāo, sem perceber que "o desarranjo da roupa. sua visivel comoção, o caminhar desordenado através da sala, os gestos, as palavras soltas" (p. 369) chamam a atençāo dos presentes e todos o observam "de um modo pouco tranqüilizador" (p. 370). E o elemento cômico intervém, quando Goliádkin, vendo à sua frente uma mesa que nāo havia sido tirada, pergunta ao empregado: "Quanto devo?" e "à sua volta todos começaram a rir, até o mesmo empregado".

O senhor Goliádkin compreendeu que acabaca de dizer um grande disparate. Procurou o lenço para fazer qualquer coisa. Mas, com surpresa geral e também dele próprio, não foi um lenço, que tirou do bolso mas um frasco que continha um medicamento receitado quatro dias antes por Krestian Ivánovitch.

E, ao cair-lhe o frasco das mãos e quebrar-se, há grande movimento e confusão na sala e Goliádkin é mais uma vez humilhado no local onde havia sido causa de escândalo: "Alguns agarram-no por um braço. Imóvel, mudo, não sente nada, não vê nada... Por fim, fö̧indo do lugar, sai da loja cmpurrando todos que o querem reter".

\section{7) Lojas:}

As diversas lojas que Goliádkin visita no início do conto, têm apenas a função de realçar a inconsistência de Goliádkin. pois entra nelas fazendo de conta que irá comprar mais do que realmente precisa, mudando constantemente de idéia e prometendo sempre voltar mais tarde para pagar. Os cbjetos que escolhe, "um serviço de chá completo", "um estojo de barba de prata", tecidos. "uma mobília de seis peças" e "algumas outras coisas úteis r. graciosas..." (p. 299) projetam sua vaidade, sua ânsia em aparentar ser rico e importante, pois eles representam o caminho à ascenção social.

\section{8) Carruagem:}

A carruagem, meio de locomoçāo empregado por Goliádkin a partir do início do conto, serve tanto como meio de projeçāo da vaidade de Goliádkin pois no primeiro dia Goliádkìn vai passar pela Perspectiva Niévski numa "carruagem azul, decorada de estranhos brasōes", cheia de guizos a tilintar c com Pietruchka na parte de trás (p. 389), como também de local de 
conflito, quando Goliádkin persegue o duplo após este o ter humilhado no café:

Agarrou-se bem ao carro e correu na rua procurando subir, o que
o outro Goliádkin tentava impedir com energia. [...] Por fim o
senhor Goliádkin conscguiu trepar para o carro. Face a face com
o seu inimigo, com as costas de encontro as costas do cocheiro.
os joelhos de encontro aos joelhos do insolente, conseguira agar-
rar com a mão direita a gola de pele do casaco do outro. (p. 368).

Os dois lutam. porém Goliádkin leva a pior. Quando "um solavanco maior o chamou à realidade", "o senhor Goliádkin, como um saco de farinha. caiu do côche, rolou" no pátio de Olsúf Ivanovitch.

E a carruagem, além dessas duas funçōes, é também o meio de transforte que afasta Goliádkin da sociedade, é o local da cena final do romance, em que, junto com Krestian Ivanovitch, recebe informações sobre uma nova moradia - o manicômio: "O senhor vai ter casa de graça com luz. aquecimento e tudo que é preciso. E mais do que merece" (p. 388). O conflito é resolvido, e Goliádkin é afastado da sociedade por romper de certo modo, a harmonia universal da mesma.

\section{9) 0 consultório de Krestian Ivânovitch:}

Tem apenas a função de mostrar a falta de habilidade de Goliádkin em relacionar-se com os outros, pois ele "ficava sempre atrapalhado quando era necessário dirigir-se a alguém para qualquer assunto pessoal" (p. 292). como também nos esclarece quanto aos problemas pessoais de Goliádkin. que procura o médico para pedir sua ajuda contra os "inimigos" que querem liquidá-lo ( $p$. 295). Mas esta confissão transforma a consulta em cena penosa, pois o médico nāo fica convencido pelas palavras de Goliádkin e ao c'espedi-lo com uma receita. Goliádkin sofre uma mudança em sua atitude c desata a chorar. Esta cena penosa no consultório faz com que Goliádkin. como em outros ambientes estranhos, se sinta enclausurado, pois ao sair do consultório, "aspirou o ar puro com uma sensaçāo de liberdade" (p. 398).

Concluindo, poderíamos dizer que há uma espécie de gradaçāo descenciente na geografia espacial do romance, que se inicia com o ambiente de festas, o local das grandes destronizaçōes e cenas carnavalescas, através da repartição, restaurante, lojas, como locais de outras cenas de conflito entre Goliádkin sozinho ou em companhia do duplo, até chegarmos ao seu quarto, prolongamento de sua própria personalidade, e finalmente aos cantos, buracos e outros esconderijos onde Goliádkin sempre deseja se meter, nos momentos de crise, e que são sintomáticos de seu desejo de sumir, de se aniquilar. A ponte, por sua vez, pela sua ambivalência como local de passagem, ¿ o cenário propício para o aparecimento do duplo.

Assim, os dois lugares extremos no espaço do romance a festa e os buracos, seriam a projeçāo dos dois sentimentos opostos que dominam em 
Goliádkin: seu sonho de ascensão social e seu desejo de desaparecer, ambos conseqüência de sua personalidade bifurcada.

\section{II.1.3 A dupla projeção do tempo da hlstória sobre o tempo de escritura: a linearidade e circularidade do elemento temporal.}

Segundo Ducrot e Todorov45 "o paralelismo idealmente existente entre o tempo da história e o tempo da escritura" é constantemente rompido em 0 Duplo: há sempre inversōes temporais, isto é, saltos do presente da narrativa ao passado e futuro, por meio das premuniçōes e sonhos de Goliádkin, como também pela mistura dos planos do real e do fantástico vistos acima. Histórias e anedotas encaixadas também interrompem a ordem da história, usadas para criar "suspense", pela suspensão da ação, como também comicidade, pelo seu estatuto de clichê.

Mas é na linearidade e circularidade do tempo que iremos nos concentrar, elementos básicos que são, na estrutura do romance:

\section{1) O tempo do discurso linear ou cronológlco:}

O tempo cronológico é minuciosamente marcado pelo ficcionista, que anota a sucessão de horas, dias e até minutos em que a fabulação se passa:

Primelro dia: cap I: Por volta das oito da manhã, Iákov Pietrovitch Goliádkin [...] acordou. [...] Durante dois minutos continuou deitado $[\ldots]$ (p. 287).

Cap. II: Na manhā de hoje (Krestian Ivánovitch) está em casa [...]. Neste momento bebe o café [...]. (p. 291).

Cap. III: Esta manhã deixou no senhor Goliádkin a impressão de um terrivel caos... [...] $\mathrm{O}$ relógio da torre deu três badaladas... [...] Depois de todas as voltas daquela mannä. tinha comprado apenas duas coisas [...] Como eram só três horas e um quarto [...] (p. 299-300).

Cap. IV: Era um dia solene, o do aniversário de Klara Olsúfievna $[\ldots]$... às nove e meia em ponto, ouviram-se as notas duma quadrilha francesa [...]. Passam tantas coisas pela cabeça dum homem que espera perto de três horas num vestíbulo obscuro e frio $[\ldots]$. Se, durante uns minutos, a copa estivesse vazia $[.$.$] .$ Espera, escondido, durante três horas. Entretanto jura a si próprio que nāo passará daquela noite. (p. $304 \mathrm{ss).}$

Cap. V: Soava meia-noite em todos os relógios das torres de Petersburgo [...]. Parecia que a esta hora [...] ninguém poderia andar nas ruas. (p. 312 ss.).

Segundo dia: cap. VI: No dia seguinte às oito horas em ponto. o senhor Goliádkin acordava na sua cama [...]. Já há um quarto de hora que estava à espera dele. [...] O tempo fugia. Eram quase dez e meia... (p. $317 \mathrm{ss}$.)

Cap. VII: Hoje toda a gente sofreu qualquer sortilégio! [...] A história do serihor Goliádkin Júnior durou três ou quatro horas.

45 DUCROT, J. \& TODOROV, T. Dictionnaire encyclopédique des sciences du langage. Paris, Seuil, 1972. p. 401. 
[...] Eram jả nove horas. O senhor Goliádkin sentia-se de excelente humor [...]. O que o atormentava deste modo era a recordaçāo do que ocorrera na véspera em casa de Olsúf Ivánovitch (p. 326 ss.).

Tercelro dia: cap. VIII: No dia seguinte o senhor Goliádkin acordou, como de costume, às oito horas [...] Sāo nove menos um quarto. São horas de ir para o serviço. [...] $O$ hóspede da véspera. [...] do qual ainda na véspera pensava que poderia vir a ser seu melhor amigo [...]. As horas iam passando lentamente. Por fim soaram as quatro (p. 332 ss.).

Cap. IX: Caminha durante meia hora, aproximadamente. [...] Que horas serão? Devem ser nove... [...] Era já muito tarde quando acordou. [...] ... "Com mil diabos, sāo duas ou três horas..." O relógio por detrás do biombo deu duas pancadas. [...] Passaram dez minutos antes que o senhor Goliádkin encontrasse outra vela c a acendesse. [...] Ao cabo de uma meia hora de esforços [...] "que diabo de idéia esta de me pôr a discutir com ele a meio da noite? - disse com um tremor docntio. [...] Uma nova luz irrompia através do nevoeiro espesso que o rodeava, havia já dois dias. [...] "Ah Quem me dera que chegue o dia de amanhā e que tudo se esclareça!" (p. 340 ss.)

Quarto dia: cap. X: Passou uma noite péssima e nāo dormiu cinco minutos. [...] Toda a noite esteve numa semi-sonolência [...] O dia ia já alto e muito claro. [...] Com grande admiração sua, o relógio só bate uma pancada. [..] Realmente o relógio marcava uma hora. [...] Logo que o nosso herói terminou este bilhete, $[\ldots]$ foi até a repartição, mas sem decidir-se a entrar, porque já era muito tarde. O relógio marcava três horas e meia. [...] Quando entrou na sala de trabalho já o dia declinava [...]. Começava a escurecer. (p. 351 ss).

Cap. XI: A noite permanecia úmida e escura como breu. [...] Deu então com a māo na carta que o escriturário lhe entregou pela manhā [...] "Espera-me hoje às nove horas em ponto [...]. Entregar-me-ei à tua proteção, às duas em ponto". [...] Um frasco que continha um medicamento receitado quatro dias antes [...] (p. 364 ss.).

Cap. XII: Pietruchka passou silenciosamente para o outro lado do tabique e declarou com toda a independência que devia faltar pouco para as oito. [...] Daqui a nada são oito horas. [...] 0 tempo estava medonho [...] como naquela inesquecível noite, à hora fatal da meia-noite, quando começara o seu infortúnio. [...] Eram nove e meia. (p. 371 ss.).

Cap. XIII: [...] ele se sentia muito tentado pelo cantinho de entrada da casa de Olsúf Ivánovitch, onde já quase no principio desta verídica história, tinha passado duas horas [...]. E havia já duas horas que o senhor Goliádkin esperava no pátio de Olsuf Ivánovitch. [...] Eu o contratei para a noite inteira... [...] Ainda è preciso esperar muito tempo? (p. $378 \mathrm{ss)}$ ).

- Esta minuciosidade de detalhes no tempo linear é contraposta ao iempo psicológico ou circular, que se opera na mente de Goliádkin, e esta repetição de uma parte do texto, como dizem Ducrot e Todorov, corresponde a um outro desdobramento de um acontecimento no tempo da escritura 46: então a dupla projeção do tempo, mencionada acima, pōe em evi-

\section{DUCROT \& TODOROV}


dência não só ambivalência entre sonho e realidade, mas também a latente loucura de Goliádkin, cm cuja mente, presente, passado e futuro se confundem. O caráter fragmentário do tempo psicológico seria pois, a projeção cio caráter fragmentado e bifurcado do herói.

\section{2) o tempo clrcular ou psicológico:}

Desde o primeiro capitulo. Goliádkin de certo modo antecipa o final da narrativa: a premonição de que algo está iminente, sugerido pela descrição do ar soturno e isidioso da luz que entra pela janela embaciada, é corroborada pelas palavras de Goliádkin "Seria bem desagradável [...] se hoje qualquer coisa corresse mal [...]. Felizmente, por enquanto tudo está correndo bem. muito bern até..." 47

Esta premonição de algo ominoso continua quando Goliádkin vê Pietruchka no meio de uma assembléia de criados, 48 falando. "Este animal, por cinco réis seria capaz de vender a alma do parceiro, sobretudo a do patrão pensou ele. - Já o fez, tenho a certeza. Apostaria em como me trocou jor um copeque" (p. 288). A premoniçāo dessas palavras nāo deixa de ser aJgo irônica, certamente, se nos lembrarmos da futura aparição do duplo.

Quando este aparece pela primeira vez, Goliádkin pensa: "Talvez este transeunte seja um enviado do Destino. Talvez năo seja por acaso que passa por aqui, mas com qualquer finalidade" (p. 314). E mais adiante: "O senhor Goliádkin sabia agora, sentia, estava absolutamente convencido de que nova desgraça o esperava e que ele ia, sem dúvida alguma, encontrar de novo - desconhecido" (p. 316). E, ao encontrar o duplo na sua cama, 4.9 "todos os seus pressentimentos se tornavam realidade; os seus pressentimentos $\mathrm{e} .$. os seus receios" (p. 317).

No segundo dia, após a aventuras da noite anterior, Goliádkin reflete sobre a veracidade ou nāo do acontecido. "Aliás, o senhor Goliádkin sabia já há muito tempo que alguma coisa se preparava lá longe, na casa dos uutros. Mas o que?" (p. 318).

Também receava ir à repartiçāo. "Tinha um pressentimento de que ali as coisas nāo iriam correr bem..." E o tempo linear é rompido ao Goliádkin. após o aparecimento inesperado do duplo na repartiçāo, pensar: "Estarei sonhando ou não? [...] $\mathrm{E}$ hoje ou ontem?". $50 \mathrm{E}$, ao alojar o duplo em sua casa. Goliádkin murmura para si mesmo, sorrindo: "Estás bêbado hoje, meu caro Iákov Pietróvitch, meu grande patife! Agora ris-te, amanhā hás de chorar, tanto mais que choramingas já és tu. Que queres que te faça?" (p. 331).

Já na manhā do terceiro dia, novamente "o senhor Goliádkin sentia [...] de modo impreciso, que as coisas nāo estavam indo bem e que o destino

$\begin{array}{ll}47 \text { Cf. } & \text { p. } 9 . \\ 48 \text { Cl. } & \text { p. } 14 . \\ 49 \text { Cf. } & \text { p. } 15 . \\ 50 \text { Ci. } & \text { p. } 8 .\end{array}$ 
lhe preparava ainda qualquer surpresa desagradável". 51 E, na repartiçāo quando o duplo finge não reconhecê-lo, após haver passado a noite em sua casa. Goliádkin murmura: "Já há muito que o pressentia. Quer dizer que está encarregado de uma missāo especial! $E$ isso". (p. 334).

Estamos portanto sendo constantemente lembrados de que algo futuro, "iminente e desagradável" está para acontecer, o que produziria uma ligação do fim com o começo do romance, além de termos a dupla projeção do tempo da história sobre o da narrativa, quando estas premuniçóes e sonhos se realizam.

Goliádkin chega até a imaginar um pacto com forças desconhecidas para se livrar do duplo:

Se algum mágico viesse dizer-me $[\ldots]$ :

'Goliádkin, dá-nos um dedo da tua māo direita e ficamos quites; o outro Goliádkin desaparecerá e seremos felizes, ficando tu apenas com um dedo a menos'. Oh! Eu dario o dedo de boa vontade. sem dizer uma palavra... Que o diabo o leve! ( $p .341$ ).

E Goliádkin continua a pensar sobre o seu duplo: "E capaz de dar cabo do meu nome, o malandrim! E preciso trazê-lo debaixo de olho..." (p. 342).

Após Pietruchka ter entregue a carta ao funcionário Vakramácv e dizer que iria "para casa de gente de juízo, de pessoas que não têm embrulhadas nem duplos..." (p. 348), Goliádkin fica profundamente abalado, com "o mau aspecto que as coisas estavam tomando" (p. 349). Mas, ao ver a carta de Vakramáiev em seu quarto, 52 Goliádkin pensa: "Eu tinha um pressentimento disto [...] e adivinho tudo que esta carta contém..." (p. 349). Ao terminar a leitura da carta. Goliádkin repete: "Eu pressentia tudo isto. mas por que me escreve ele esta carta? [...] Ah! Quem me dera que chegue o dia de amanhã e que tudo se esclareça!" (p. 350). Tudo será realmente esclarecido "amanhā", mas não da maneira como Goliádkin imagina. A compreensāo de seus pressentimentos vem com a realizaçāo dos mesmos e o "nevoeiro espesso que rodeava suas idéias, e que também havia rodeado sua pessoa ao encontrar o duplo na ponte e até penetrado em seu quarto, no inicio da narrativa, este nevoeiro é iluminado por "uma nova luz" (p. 350).

A dupla projeção do tempo é mais uma vez observada quando Goliádkin. após uma noite péssima, é oprimido por "recordaçöes confusas, pesadelos horriveis, sensaçōes desagradáveis": 53 estes sonhos premunitórios misturados com pesadelos e lembranças, serāo posteriormente projetados na narrativa de modo tão hábil, que, como já mencionado, os limites entre real e fantástico e entre presente, passado e futuro se esvanecem.

Os "maus sinais" se sucedem, no quarto dia: o duplo sobe rapidamente as escadas da repartiçāo e Goliádkin pensa: "Mau sinal [...] as coisas estāo ficando pretas. Ah! meu Deus!" (p. 358-9). Na repartiçāo, Goliádkin sente

51 Cf. p. 9.

52 CI. p. 9.

53 Cf. p. 10. 
que os colegas o olhavam de modo estranho: "Era mau sinal. O senhor Goliádkin sentiu-o e, sensatamente, preparava-se para nāo prestar atenção ao fato, quando um acontecimento inesperado o aniquilou de repente $\mathrm{e}$ deu cabo dele" (p. 359). E o seu segundo sonho, de sua "destronizaçāo" pelo cluplo, que o insulta com gestos carnavalescos no meio de seus colegas, que se torna realidade; ${ }^{54} \mathrm{e}$. logo após ter sido caluniado pelo duplo, scu primeiro sonho se realiza: com um olhar frio, Andriéi Filipovitch nega-lhe acesso ao ministro. 55

Mais tarde, na taberna, an derrubar o medicamento receitado por Krestian Ivánovitch 56 e ao ver o "ar sinistro" do "liquido repugnante e vermelho escuro", Goliádkin pōe-se a tremer e pensa: "A minha vida está em perigo" (p. 370). Palavras de mau agouro, como também sua resposta ao porteiro que lhe traz um sobrescrito oficial, em sua casa: "Já sei, já sei tudo [...] E oficial..." (p. 370).

Suas palavras de despedida a Pietruchka contêm alusōes a seu futuro, por outro lado, do qual ele não está consciente: "Eu também vou partir... Cada um segue seu caminlo e não se sabe quando nos voltaremos a encontrar" (p. 372). São palavras trágicas e irónicas, pois Goliádkin pensa em sua fuga com Klara, enquanto o ieitor saberá que Goliádkin será levado embora, no fim do conto, a um manicômio.

Da mesma maneira como suas premoniçōes, as lembranças de Goliádkin também projetam duplamente o tempo da história sobre o da narrativa: ao ir à rua Litićinaia. Goliádkin enfrenta um tempo medonho, com a neve a cair. "como naquela noite inesquecivel, à hora fatal da meia-noite, quando começara o seu infortúnio" (p. 374).

Sua intenção de se lançar aos pés de Sua Excelência e pedir sua ajuda. pois, "um bom chefe deve intervir numa circunstancia destas [...]. Dir-lhe-ei que o estimo como se fosse meu pai e como o melhor dos chefes, que lhe confio a minha vida e que me retirarei da vida publica!" (p. 374) é lançada novamente na escritura de modo fragmentado, refletindo sua angústia interior: "Eu pensava que seria uma atitude sobre... Eu considero o meu chefe como um pai, Projeta-me, pe... peço-lho... a cho... rar. Será uma boa ação..." (p. 376). Mas a "proteção" que ele vai receber, é aquela que ele já há muito tempo "pressentia"...

Quando o encaminham para fora do gabinete da casa de Sua Excelência. Goliádkin pensa: "Foi exatamente como em casa de Olsuf Ivánovitch" (p. 377) c esta mesma repetição em relação ao passado se dá quando ele espera duas horas no pátio de Olsuf Ivánovitch, "onde já quase no princípio desta vcrídica história, tinha passado duas horas". 57

Ao tentar raciocinar sobre sua situação, outra vez prognostica algo que virá acontecer, mas nāo como ele o imagina: "Admitamos que as coisas se

54 Cf. p. 10.

55 Cf. p. 10.

56 Cf. p. 25.

57 Cr. p. 26. 
compunham. O pouco dinheiro que tenho ainda me chegaria por algum tempo. Basta-me-ia um pequeno quarto, meia dúzia de móveis. Já nāo terei Pietruchka e passaria muito bem sem ele. Seria apenas um hóspede" (p. 380 ). E o que lhe dira o médico, na cena final: "O senhor vai ter casa de graça $[\ldots]$ E mais do que merece..." 58

Um pouco antes da cena decisiva em casa de Olsúf Ivanovitch, Goliádkin ulitra vez decide que a partir deste momento podia considerar-se alheio a tudo que acontecesse". (p. 383). De agora em diante, suas açōes são ainda mais sem nexo. Levado pelo duplo para dentro do salāo do Olsúf Ivánovitch. apinhado de convidados, Goliádkin pede ao sósia que o socurra e não o abancione neste momento crítico em que "ia começar uma vida nova" (p. 385). São palavras que irão se concretizar daqui a pouco. E, rodeado pelos convidados, em silêncio solene, todos parecendo esperar "um acontecimento extraordinário", Goliádkin pensa: "parece exatamente aquilo que se passa numa familia quando um dos seus membros vai partir para uma viagem longínqua... Só falta as pessoas levantarem-se e rezarem..." (p. 385).

Antes do "beijo de Judas" que o duplo lhe dá, "julgou ver uma multidão numerosa de Goliádkini absolutamente iguais, que forçavam um ruído a poria da sala" (p. 386): é uma parte do pesadelo que Goliádkin tivera. E a porta do salão se abre, Goliádkin sente-se gelar ao ver o recém-chegado: "Mas não tinha ele previsto já tudo isto? Não o tinha pressentido?" (p. 386).

Finalmente, após o escândalo final, Goliádkin é levado pelo médico ao manicômio, onde vai ter "mais do que merece..." (p. 388): e "o senhor Goliádkin deu um grito e pós as mãos na cabeça. Ai dele! Já há muito presscntia que, mais tarde ou mais cedo, isto havia de acontecer...". 69

Deste modo, através da repetiçāo de uma parte do texto que corresponde 'a um outro desdobramento de um acontecimento no tempo da escritura. apresenta-se a dupla projeção do tempo da história sobre o tempo da escritura. A narrativa deixa de ser linear para tornar-se circular, pois a preınoniçāo de Goliádkin une o fim ao começo da história, enquanto as partes centrais são também projetadas duplamente pela ambivalência do presente, passado e futuro e pela umbivalência sonho-realidade.

\section{II.1.4 A pollfonla no foco narrativo}

Para Bakhtinć, a polifonia ou dialogismo, junto com a carnavalização. sāo dois traços fundamentais na obra de Dostoievski: trata-se da pluralidade dc vozes e visões, da qual nenhuma é objeto de definição psicológica ou sociológica, mas que são todas sujeitos, em estado de se responderem reciprocamente. $O$ conceito de polifonia também abrange a pluralidade das idéias. inseparáveis das vozes que as portam.

$58 \mathrm{Cr}$. p. 28.

59 Cf. p. 12. 
E essa polifonia que provoca uma focagem bilateral da narrativa, pois, sc em O Duplo, a narrativa é conduzida na terceira pessoa. “le récit à la troisiéme personne [...] n'empêche ni la forte presence du narrateur, ni la réduction de la distance entre lui et les personnages, ni le caractère limité dc sa connaissance sur les motivations du héros", segundo Todorov. Isto concorda perfeitamente com a magistral análise que Bakhtine nos faz do "estatuto do narrador" em 0 Duplo: 60

\begin{abstract}
a narrativa é dialogicamente virada para o próprio Goliádkin, ela ressoa em seus ouvidos como a voz zombateira do outro, se bem que do ponto de vista formal a narrativa esteja dirigida ao leitor [...]. Também na estrutura desta narrativa com duas vozes que interferem, notamos o cruzamento de duas réplicas, mas invertidas: a réplica do outro absorveu a do herbi [...]. Entretanto, o narrador imprime as palavras de Goliádkin uma entonação zombeteira e reprovadora, que se transforma imperceptivelmente em discurso do próprio Goliádkin [...]. O resultado é uma estrutura bivocal quebrada [...] e as fronteiras movediças entre a narrativa e a palavra do herói apontam todas para a narrativa como o prolongamento direto da segunda voz de Goliádkin [...]. A obra inteira está assim construída, como uma troca interior contínua entre duas vozes, no quadro de uma consciência decomposta. Cada momento essencial se situa na intersecção de três vozes: o discurso direto de Goliádkin, a narrativa do narrador e o discurso do duplo [...]. Elas cantam a mesma coisa, mas com sua própria partitura... Não se trata ainda de polifonia, mas já não é mais um homofonia, pois a mesma palavra, idéia e fenómeno, passam por trés vozes e têm um timbre diferente em cada uma delas [...].
\end{abstract}

Poderfamos ainda acrescentar à análise de Bakhtine sobre o foco narrativo, o fato de o narrador falar nāo apenas da personagem, de si e ao lcitor, mas também da propria narrativa, como segue:

1) $O$ narrador fala de personagem: "Por volta das oito da manhă, Iakov Pietróvitch Golládkln, funcionário numa repartiçāo pública, acordou. Tinha dormido durante muito tempo" (p. 287).

2) O narrador fala ao leitor, de sl o da narrativa: "Se eu fosse poeta como Homero ou Púchkin - talento menor que o deles não bastava - desejaria pintar, oh leitores! - com cores brilhantes em hábil pincel, este dia triun\{al. Seria pelo jantar que havia de começar o meu poema" (p. 305).

"A minha pena não basta para pintar como devia o baile que a extraordinária gentileza do velho dono da casa improvisou. Como poderia eu, aljás modesto narrador das aventuras do senhor Goliádkin - curiosas no seu gênero. lá isso é certol - como poderia eu exprimir esta amálgama surpreendente de beleza, de brilho, de elegância, de alegria, de amabiblidade e de júbilo;..." (p, 306).

"Mas - oh leitor! - tive já ochasião de dizer que a minha pena não é capaz de um tal esforço, por isso vou parar. Voltemos antes ao senhor Go-

60 BAKHTINE, p. 282-6. 
liádkin, único herói desta novela verídica. A situaçāo em que se encontra é a mais estranha possível" (p. 306).

Entāo onde está ele afinal? Coisa estranha! Está no patamar da escada de serviço da casa de Olsuf Ivánovitch. [...] Enquanto espera, observa gs acontecimentos como um espectador indiferente. Observa e nada mais, meus senhores". (p. 307).

Observamos aqui, a sutil passagem da narrativa em terceira para a primeira pessoa: "Contudo, podia entrar. Por que nāo entra? Bastar-lhe-ia dar um passo... vai talvez entrar daqui a pouco".

"Eis aqui, meus senhores, a situação em que se encontra o herói desta veridica história" (p. 307).

"Este senhor tem cabeleira postiça - pensa o nosso heról" (p. 310) "O nosso herói dispós-se a esperar tranquilamente, durante duas horas, o regresso de Pietruchka" (p. 345). "O pobre senhor Goliádkin" [...] "O honestíssimo senhor Goliádkin"... (p. 352). "Mas afinal nāo me disse - como tem passado? - insiste com voz melosa o desconcertante sósia do nosso herói" (p. 366).

"Nâo se pode pensar em viajar com um tempo destes - dizia para si - nosso desgraçado her6i" (p. 374).

"A bem dizer, ele se sentia muito tentado pelo cantinho de cntrada da casa de Olsuf Ivánovitch, onde já quase no princípio desta veridlca história, tinha passado duas horas [..." (p. 378).

O desgraçado senhor Goliádkin Sênior olhou pela última vez aquela gente e as coisas em volta e, tremendo como um gato que tivessem mergulhado em água fria - se é licita tal comparaçăo! - instalou-se no carro (p. 387).

Vê-se então como há uma fronteira realmente movediça, como diz Bakhtine, entre o narrador falando da personagem, da narrativa, da história, de si c ao leitor, ao mesmo tempo parodiando o herói, a si e a narrativa: "A narraçāo de Dostoievski está sempre privada de perspectiva. Seu narrador está na proximidade imediata do herói e do acontecimento corrente, ele leva sua narrativa sem a mínima distância sobre o fundo". 61 Além disso, a intençāo paródica é claramente percebida, pela gradaçāo nos adjetivos usados para clescrever o herói: "o senhor Goliádkin", "o herói", "o nosso desgraçado herói", "o desgraçado senhor Goliádkin Sênior", "o pobre senhor Goliádkin", "c honestíssimo senhor Goliádkin".

Mas é realmente no estatuto da personagem que vernos a polifonia em todo o seu alcance, através da bivocalidade da fala do herói:

61 BAKHTINE, p. 292. 


\section{II.1.5 0 estatuto da personagem: \\ 1. A palavra bivocal "divergente" de Golládkin}

Falando dos diferentes tipos de palavras na prosa de Dostoievski, observa Bakhtine que elas pertencem a categorias variadas, com traços especificos, mas ć a palavra divergente bivocal que predomina, a palavra interiormente cialogizada e a palavra do outro refratada. surpreendendo a alternância brusca de diferentes tipos de palavras. 62

Já havendo Bakhtine explorado a palavra no monólogo do herói e a ralavra divergente em 0 Duplo (cujos pontos principais seriam: 1) o discurso de Goliádkin procura fingir sua inteira independência em relação à palavra de outrem; 2) ao larło da indiferença simulada, vem a vontade de se esconder, ficar invisivel, procurando convencer a si mesmo e também a outrem; 3) a submissão a outrem, como se tais idéias fossem realmente as suas. O diálogo permite substituir a voz de outrem pela sua própria voz; mas esta segunda voz de Goliádkin, fechada e satisfeita, não chega a se fundir com sua primeira voz, hesitante e timida. O herói quer fazer tudo sozinho, mas isto toma a forma de "nós mesmos", "tu e eu". Todas estas vozes mantêm relações complexas, fornecendo matéria para uma intriga, pois o acontecimento real não é descrito, serve apenas para atualizar o conflito interior que $\varepsilon$ o verdadeiro assunto da novela), basta-nos apenas mencionar mais alguns itens em relaçāo à funçāo bivocal da fala em Goliádkin, como frojeçāo de sua personalidade desdobrada:

E básico, para compreendermos o estatuto da personagem, analisarmos a voz de Goliádkin, como o nível inferior e mais fundamental da fala, e considerada por Sapir como "uma espécie de gesto" que toma parte no "jogo l:ímico total" da comunicação. 63 Sapir também afirma que "há na voz do indivíduo um quê de indicativo da sua personalidade" e que a voz "é de certa maneira um índice simbólico da personalidade total" e "em grande parte uma simbolizaçāo inconsciente da atitude geral da pessoa".6.t

Aplicando estes conceitos à voz de Goliádkin e de seu duplo, notamos que há uma gradação ascendente na voz do duplo, que no começo de sua "usurpação" fala em voz baixa, como o próprio Goliádkin, ao passo que gradativamente sua voz vai ficando mais forte, até dominar a do herói. Basta compararmos as vozes de ambos, para perceber o contraste:

A primeira vez que ouvimos Goliádkin falar, é em voz baixa: "Seria bem desagradável - disse balxinho para si próprio -" (p. 287), como se esta afirmaçāo a voz baixa fosse necessária para convencê-lo interiormente de que tudo estava bem.

62 BAKHTINE, p. 264.

63 SAPIR, Edward. Lingüistica como ciência. Rio de Janeiro, Acadêmica, 1969. p. 66 .

64 Ibid., p. 68-9. 
, Ao vestir as botas novas, murmura "entre dentes palavras ininteligiveis" (p. 289). Goliádkin fala sempre baixo e atrapalha-se ao ter de falar com alguém que não seja seu criado:

o senhor Goliádkin, que ficava sempre atrapalhado quando era necessário dirigir-se a alguém para qualquer assunto pessoal, 65 também para essa ocasiāo nāo tinha preparado a primeira frase, o que, em circunstâncias tais, constituía sempre para ele um verdadeiro obstáculo. Fica muito atrapalhado, balbucla umas palavras ininteligíveis, certamente palavras de desculpa, e depois, como não sabe o que há de dizer, puxa uma cadeira e senta-sen (p. 292).

Ao encontrar o duplo pela primeira vez, este lhe fala "com uma voz rápida e sacudida, não muito clara" (p. 313), como sua própria voz. que vai aos poucos se desintegrando com as diversas "destronizaçōes" que vai sofrendo: ao se queixar a Anton Antônovitch sobre a chegada do duplo na repartiçāo, gagueja e chora, não compreende nada. E. à saída da repartição, quando o duplo se aproxima dele, Goliádkin lhe fala com voz fraca: "Senhor - disse por fim o senhor Goliádkin com uma voz fraca que parecia um murmúrlo e sem ousar olhar para o amigo - parece-me que os nossos caminhos são diferentes..." (p. 325). Curiosamente, a voz de Goliádkin diminui e aumenta em função do poder de sua personalidade; quando esta enfraquece. perde a voz e vice-versa. Neste mesmo episódio, após haver falado ao duplo num "murmúrio", parece que o herói faz um esforço e, após um curto silêncio, acrescenta "em tom severo": "Julgo que não é preciso dizer mais nada...", enquanto o duplo, ainda tímido, incipiente, pede-lhe desculpas pela sua "ousadia" e diz: "Se o senhor Iákov Pietrovitch... quisesse ter a bondade de ouvir-me..." (p. 326).

Após o duplo ter dormido em sua casa e sumido na manhā seguinte, a roz de Goliádkin "mal se ouvia" ao perguntar a Pietruchka: "Onde está ele? Onde está?", "apontando para o lugar onde na véspera o hóspede se tinha deitado" (p. 332).

Mas já no próximo encontro na repartição, a atitude do duplo mudou, e. ao ser interpelado por Goliádkin, o duplo lhe responde: "Desculpe-me, depois, depois me poderá falar!" (p. 333), ao que Goliádkin murmura: "Temos rova história!" Posteriormente, após o "desafio" do duplo ao lhe perguntar "Dormiu bem esta noite?" (p. 337) e após o beliscão e piparotes que ele dá em Goliádkin, este readquire um pouco sua força e agarra o duplo pela gola do casaco, na safda. Invertem-se aqui por um instante os papéis, pois o duplo. "um pouco estupefato e um tanto assustado", pergunta a Goliádkin "Que deseja de mim", "com voz fraca", ao que o herói responde: "Se ainda tem um resto de vergonha, espero que o senhor se lembre de nossas relaçōes de ontem" (p. 340). Mas imediatamente o duplo readquire sua anterior ascendência sobre Goliádkin, através da ironia:

65 Cf. p. 26. 
Ah, ótimo! E entāo? Dormiu bem?

A raiva paralisou por um momento a língua do senhor Giliádkin. Dormi bem, dormi... Mas faço questão dizer-lhe que o senhor se vai dar mal com a sua brincadeira...

- Quem the disse isso? Isso é os meus inimigos dizem!... respondeu com voz entrecortada o outro senhor Goliádkin, escapando-se das mạas do verdadeiro senhor Goliádkin. (p. 340).

Ao pensar consigo mesmo sobre sua situaçāo, Goliádkin diz, "baixañōo um pouco a voz": "claro que seria muito melhor que nada disto tivesse acontecido. que nāo houvesse gêmeos nenhuns..." (p. 342).

Os gritos que dirige a Pietruchka, quando este não acorda, pöe ainda mais em contraste sua voz normalmente fraca e entrecortada: "Patife Eritou o senhor Goliádkin. - Porcalhão, queres dar cabo de mim?" (p. 347). Mas, ao ouvir Pietruchka the explicar o que Vakramáiev lhe havia dito, Goliádkin assustado. the responde "em voz quase inaudivel": "Ah, meus Deus! E o endereço? Com os diabos! Deu-te?" (p. 348). O mesmo acontece ao responder à confissão de Pietruchka de que iria para casa de pessoas "que nāo têm embrulhadas nem duplos", com "uma voz que mal se ouvia": "Vai dormir, maroto. Amanhã conversaremos" (p. 348).

A mesma variação observamos também ao Goliádkin se dirigir "resolutamente, espantado da sua própria coragem" ao chefe Andriei Filípovitch, para pedir-lhe licença para falar com Sua Excelência. Aos poucos, vai perdendo sua auto-confiança, até que "a voz do senhor Goliádkin tremeu, o resto tornou-se vermelho e duas lágrimas apareceram a brilhar-lhe nas pestanas": "Espero - disse baixinho e com voz trêmula - espero que ao menos ¿ senhor, Anton Antônovitch queira ouvir-me e julgar o meu caso", diz um pouco depois a seu amigo. (p. 361).

Seu duplo o domina completamente agora. A saída da repartiçāo, Goliádkin o persegue, dizendo-lhe "Cavalheiro, cavalheiro, espero que...", ao que o duplo responde: "Nāo, não espere coisa nenhuma" (p. 364).

Ao dialogarem francamente no café, o “tom conciliador” de Goliádkin se transforma aos poucos numa voz "cada vèz mais fraca" (p. 366) e, à pergunta feita "com voz melosa" pelo "desconcertante sósia do nosso herói", Goliádkin responde "em voz balxa": "De vez em quando tenho tosse" (p. 367). Sua voz também é "hesitante" ao perguntar ao empregado quanto devia, à saída da taberna em que se encontrava pouco depois. 66

E também "fraca e triste" a sua voz ao receber o sobrescrito oficial que lhe comunicava sua demissão do emprego: "Já sei, já sei tudo" (p. 370).

No encontro final em casa do ministro, o duplo e Goliádkin se desafiam mutuamente, mas é o duplo que leva a melhor:

66 Cf. p. 25. 
O seu ar resoluto, os seus gestos, tudo nele significava que se sentia senhor dos seus direitos.

- Dê-me licença que lhe pergunte - disse, dirigindo-se agora ao seu rival - diante de quem é que o senhor julga que está falando? Diante de quem está o senhor? Em casa de quem?

O senhor Goliádkin Júnior estava vermelho de comoção e tremia de indignação e de cólera. Tinha lágrima nos olhos (p. 377).

E, a pérfida voz do duplo soa como "falsete", quando, após a "destronização" de Goliádkin, mete-lhe o sobretudo pela cabeça abaixo: "O sobretudo. o sobretudo... do meu melhor amigo!" (p. 377), parodiando a voz de Goliádkin.

Tímida e entrecortada é a voz de Goliádkin ao se despedir de todos, antes de entrar na carruagem que o levará ao manicômio: "Espero não ter feito nada de censurável [...] nas minhas relaçōes oficiais" (p. 387), como tamtém o é ao dirigir-se a Krestian Ivânovitch na carruagem: "... eu creio que não fiz mal nenhum", "tremendo e procurando, pela sua submissão e humilclade, provocar a piedade do terrivel Krestian Ivânovitch" (p. 388).

- Assim, a gradação das vozes observada em Goliádkin e em seu duplo, Frojetariam a maior ou menor ascendência da personalidade de um sobre a do outro, além de ambigiizarem, em Goliádkin, o limite entre monólogo e diálogo, entre pensar e falar em voz baixa.

Poderíamos ainda mencionar os clichês que Goliádkin emprega, como "Quem sabe esperar alcança sempre o que deseja" (p. 307), "Oh, a natureza humana!... Como somos covardes! Ter medo é a nossa sina" (p. 308) "O melhor é esperar e sofrer" (p. 324), "Contanto que nāo incomode ninguém" (p. 324), "A natureza assim quis e sabe o que faz" (p. 330), "Agora ris-te, :manhã hás de chorar" (p. 331), "O descaramento nāo aproveita a ninguém", "Sairei vencedor pela resignação" (p. 340), etc. Estas frases estereotipadas também exercem dupla função, pois além de enfatizarem a falta de originaljdade de idéias em Goliádkin, mostram também o lado paródico dessas afirmaçōes, pois o duplo sentido dos clichês, em relação ao próprio Goliádkin $\epsilon$ evidente, e os clichês funcionam "às avessas" para ele.

Estes clichês, por outro lado, como "linguagem ou estilo elevado", poderiam ser contrapostos à "linguagem livre e familiar ou estilo baixo" - outra característica da Menipcia - de que Goliádkin faz uso, principalmente ao se referir aos superiores, desfazendo-os: o médico é um "medicastro", "imbecil". "parvo" (p. 298), seu chefe é um "urso" (p. 300) "idiota", "malandro" (p. 324), os jesuitas cram "uns perfeitos cretinos. Que fossem todos ao diabo!" (p. 307), Ivân Semiônovitch é um "macaco velho", o duplo é "o malandro", o "falsário" e até a si próprio Goliádkin acusa de "imbecil" (p. 328) por ter se preocupado com o duplo. Pietruchka é um "patife, canalha, porcalhāo" (p. 347), além de "maroto" e "beberrāo", enquanto a velha alemã. dona da pensão onde ele morara, é chamada de o "diabo da velha" (p. 357), e Vakramáiev ẽ "estúpido" e "burro" (p. 356). 
Por outro lado, Goliádkin se considera "um homem igual aos outros" (p. 292), "simples, honesto, correto, cordial" (p. 325), que "nāo procura fazer mal a ninguém" (p. 295), que não usa "máscaras" (p. 301).

Enfim, se as palavras de Goliádkin sāo ironizadas na boca do duplo e na própria narrativa, elas também o săo na boca de Pietruchka, que semFre repete as ordens do patrăo, com um "coup d'oeil de côté", como Baktine chama a palavra de outrem refletida. Também as ridicularizações que Goliádkin faz dos outros. - como dos convidados na festa de Olsuf Ivánovitch ("Est€ senhor tem cabeleira postiça" (p. 310) - poderiam ser contrapostas à sua própria ridicularizaçāo na frente dos outros, cada vez que deve tomar uma atitude ou se impor.

Estes poucos elementos que fazem parte da palavra bivocal "divergente" na narrativa de $\mathbf{O}$ Duplo, além dos comentados por Baktine serviriam pois, para revelar a íntima relação entre palavra-personagem. porque é através đa fala, através das diversas categorias de palavras, que o herói se revela a nós em toda sua complexidade. Grossman também comenta que Dostoiévski introduziu o "diálogo interior" no romance exatamente para revelar a "bifurcaçāo da consciência, a fragmentaçāo da personagem principal". e "esta forma rebuscada de auto-análise" já é estabelecida pelo "sistema estilístico de ( s6sta". 67

\section{A carnavalização na máscara de Golládkin e do duplo}

A aparência física de Goliádkin, da qual "o rosto ensonado, um tanto gasto" e os "olhos semi-cerrados" já foram comentados, 68 ainda falta acrescentar seus "olhos cinzentos" que brilham de maneira estranha ao falar com Krestian Ivânovitch (p. 295), sua calvicie e sua miopia, que não lhe permite olhar ao longe (p. 314), além de seu andar levemente ritmado. Se estes traços realmente nāo poderiam fazer dele alguém que se sobressalsse dos demais, como ele mesmo o diz ("sou um homem igual aos outros" p. 292 e 313). seus trajes entretanto, revelam sua vaidade em querer ser mais do que os outros. Seu "travestissement" é completo, desde as calças quase novas, uma camisa com botões dourados, um colête de florinhas de cor clara, bonita. uma gravata de seda furtacores e a flamente casaca de seu uniforme, além das botas novas (p. 289). Pietruchka, por sua vez, também está fantasiado dos pés à cabeça, com uma libré muito maior do que sua altura. com galōes dourados, chapéu de plumas e espada na cinta. mais o fato de estar descalço (p. 288-9). A carruagem azul de que ambos se servem, para i) à Perspectiva Niévski, contrasta com sua cor e com seus guizos e brazões, com o aspecto colorido dos trajes de ambos.

O duplo por sua vez, em tudo idèntico a Goliádkin (p. 317), também usa roupas grandes demais: "Podia-se compará-lo a alguém que, nāo tendo

67 GROSSMAN, Dostoievski artista, p. 52.

$68 \mathrm{Cf}$. p. 14. 
roupas próprias, vestisse as de outra pessoa: as mangas sāo compridas demais, a cintura fica-lhe muito acima. Puxa constantemente o colête que está curto, encolhe-sc, procura sumir-se" (p. 326). Ambos têm o mesmo nome, a mesma aparência, não são de Petersburgo, trabalham na mesma repartição. Entretanto, a semelhança fisica entre ambos não é corroborada pelas suas personalidades: enquanto Goliádkin é submisso, insignificante, se bem que honestíssimo e bom, seu duplo é exatamente seu contrário - bajulador, falso, malévolo, covarde, paródico.

Se os gestos de Goliádkin sāo "carnavalescos" "malgré soi", os do duplo 's são propositadamente: Goliádkin vai "descalço e com a roupa com que tinha dormido" até a janela de seu quarto, para ver o que estava acontecendo no pátio (p. 287), enquanto vai "em pontas de pés" à mesa para examinar seu tesouro, tão bem escondido "no cantinho" da gaveta, como ele próprio sempre queria se esconder (p. 288). Goliádkin, sempre que observado, substitui seu ar de alegria por um aspecto compenetrado e grave (290) e sua indecisão é revelada ao ser reconhecido pelo chefe, passeando de carluagem; "Devo cumprimentar ou nāo? Dou-me a conhecer ou faço de conta que não sou eu?" (p. 290) iniciando assim um processo de desagregaçāo da personalidade que atinge seu ápice ao encontrar seu duplo. Seus gestos constantemente contradizem suas idéias. Arrepende-se do que fez, de nāo ter cumprimentado o chefe, deveria ter-se "mostrado natural, ter tomado $\overrightarrow{0}$ ar superior e desempoeirado, próprio das pessoas duma certa condição" (p. 290). Sua indecisão torna-se de novo aparente quando hesita diante da casa do médico, e mesmo ao puxar o cordão da campainha, ainda pensa: "Não seria melhor deixar para amanhā? Nāo é absolutamente necessário que seja hoje..." (p. 291). Gosta de observar os outros "disfarçadamente", tanto os colegas na repartição, ao fingir ler papéis, quanto em casa, ao observar Pietruchka.

Sua conduta inconsequente é também aparente na inconsistência de seus gestos: lança olhares provocantes aos outros, que contrastam com sua afetáda humildade. Ao encarar o médico, opera-se uma estranha transformação nele, seus olhos brilham, os lábios se agitam e os músculos e traços do rosto se movem, quase como se estivesse hipnotizando-o pela reação que o médico tem:

Krestian Ivânovitch parecia pregado na cadeira. Estupefato, olhava com uns olhos muito espantados o cliente, que por sua vez, o olhava também. Por fim o médico ergueu-se puxando de leve o paletó do senhor Goliádkin. Durante momentos ficaram os dois silenciosos, imóveis, sem deixarem de se fitar. Depois deu-se uma esquisita mudança na atitude do senhor Goliádkin. Os lábios começaram a tremer-lhe, o queixo a mexer $e$, de repente. desatou a chorar (p. 295).

Algo semclhante ocorre ao Goliádkin fitar seu chefe, Andriéi Filípovitch. na escada da casa de Olsuf Ivânovitch: 
O senhor Goliádkin continuava embaixo, na escada. Seu chefe, do alto, parecia prestes a cair sobre ele. Quase sem dar por isso, deu um passo para a frente e Andriéi Filipovitch recuou. $O$ senhor Goliádkín subiu dois degraus. Andriéi Filípovitch olhou à sua volta com inquietação. De um pulo, o senhor Goliádkin tornou a subir a escada, Andriéi Filípovitch correu a toda pressa e fechou a porta atrás de si (p. 303).69

Seu "ar importante" ao encontrar colegas contrasta com seu desejo de meter-se num buraco, de esconder-se a si próprio, de reduzir-se a po,70 quando as coisas não lhe correm bem, assim como "aqueles olhares dardejantes que, segundo acreditava, já por duas vezes o tinham salvon (p. 301-2) contrastam com sua vermelhidão, seu olhar baixo, sua atitude canhestra ao tentar falar em público (p. 309).

O duplo, ao contrário, é "carnavalesco" por premeditação: os beliscões, niparotes, a familiaridade com que trata Goliádkin o "beijo de Judas" que lhe dá, os empurrōes por detrás, o casaco que ele lhe mete cabeça abaixo,71 tudo revela a intenção malévola do senhor Goliádkin número II em relação ao senhor Goliádkin número I. O "sorriso satisfeito" de Goliádkin é refletido cibliquamente como "sorriso mau" (p. 386) nos lábios do duplo e é mais t:ma vez parodiado no "sorriso mal dissimulado" de Pietruchka (p. 288), enquanto sua falta de destreza ao tentar dançar com Klara Olsúfievna, reflete-se nos movimentos do duplo, que “dava passinhos por entre os grupos das pessoas. Parecia que de um momento para o outro se ia pòr a dançar..." (p. 386). Se Goliádkin "enterra o chapéu até as orelhas" quando o duplo o encara. por "duas ou três vezes a aba do casaco do desconhecido" lhe roça o nariz ao entrar em sua casa (p. 317). Todas as açōes e gestos do duplo são amplificados e distorçidos parodicamente, em relaçāo a Goliádkin, assim como o foram suas palavras.

Quebra-se desta maneira o monológico da narrativa, através da ambiguiicade que a carnavalização traz a todas as ações do herói e de seu duplo. transformando novamente a tragédia em paródia da tragédia, ou seja, em comédia. Assim, as açōes antitéticas mas complementares de Goliádkin de "ser como os outros" e ao mesmo tempo suas ambiçōes sociais, sua vaidade que é projetada no duplo - ele é tudo que Goliádkin gostaria de ser - e refletida de volta através deste, em Goliádkin. faz com que a personalidade ceste último vá se desintegrando, até ser vencida pela do duplo, até ele ser "aniquilado pelos inimigos". E as palavras de Goliádkin a respeito de seu duplo, quando este dorme em sua casa, "Que figura tristel Parece um mendigo!" (p. 332) são dirigidas a si mesmo, pois no final do romance a usurpação do duplo completa-se, com o afastamento de Goliádkin da sociedade: nada the sobrou, a não ser ter "casa de graça, com luz, aquecimento e tudo

$69 \mathrm{Cl}$. p. 24. Lembremo-nos também de que o hipnotismo é explorado por Dostolevski, conorme diz GROSSMAN, junto com os fenómenos de dupla personalidade e manias, em $O$ Sósia (p. 162, Dostoievski artista)

$70 \mathrm{Cr}$. p. 27.

71 Ci. p. 37 . 
que é preciso" (p. 388). Assim, a história que, para Goliádkin, deveria ter terminado com um "todos viviam contentes e felizes", como nos contos de fadas, termina com Goliádkin transformado num "pobre diabo". (p. 339), cujas "ambiçōes e sentimentos" são calcados e desprezados por todos.

Segundo Temira Pachmuss, Dostoiévski desenvolve o tema da vaidade cm O Duplo como "an evil manifestation of man's animal self" e Goliádkin, cuja única ambição é ser aceito e admirado por colegas e superiores, vê serem fúteis seus esforçcos de bajulação, intrigas e afetação de prendas sociais. Ao ser expulso da festa e descobrir que não consegue ter sucesso social e qque a gratificação de seu ego ambicioso nāo é mais possível, Goliádkin, tenco de escolher entre apatia ou suicídio, consegue sair do dilema recusando considerar a vaidade como sendo sua. Ele não consegue refrear seus desejos ce igualar seus superiores e estes desejos aparecem-lhe sob a forma de um cutro ser que se levanta contra ele. $O$ duplo é um intriguista, um hipócrita, um carreirista sem escrúpulos, uma incarnação de tudo que Goliádkin não se permite ser. Ele luta com o duplo e tenta apaziguá-lo, está até preparado a degradar-se ante o duplo, o que é um tormento para o ego de Goliádkin. Mas o duplo é o mais forte e Goliádkin é derrotado, levado ao desespêro e finalmente levado a um asilo de loucos. 73

Finalizando, vemos mais uma vez como o estatuto da personagem, através da funçāo bivocal da fala e através da máscara de Goliádkin, com sua aparência física, gestos, açōes e desejos, revela perfeitamente a personalidade fragmentada do herói, como também a revelaram os outros aspectos da starrativa. E, se para Temira Pachmuss a vaidade não realizada seria a causa primeira para o aparecimento do duplo, achamos que esta interpretação seria um pouco simplista, se bem que perfeitamente aceitável, levando em consideraçāo a ambivalência com que o próprio Dostoiéski marcou a personalidade fragmentada de seu herói. Acreditamos poder ir um pouco mais além. tentando aproximar o simbolismo inerente a todos os objetos, - e que coaduna perfeitamente dentro do esquema de carnavalização de Bakhtine (as imagens carnavalescas têm natureza ambivalente, elas são sempre duplas, reunindo os dois polos da mudança e da crise: o nascimento e a morte, a benção e a maldiçāo, lisonja e a injúria, a juventude e a decrepitude, $n$ alto e o baixo, a face e o verso, a bobagem e a sabedoria 73), - do contexto de duplicidade e fragmentação da estrutura, para chegarmos a uma interpretaçāo de 0 Duplo um pouco mais aprofundada.

\section{II.2 A duplicidade e seus derivados no simbolismo de O Duplo: II.2.1 No cenário:}

o quarto de Goliádkin é caracterizado como cheio de po, cujo sentido regativo relacionado com morte, como estado de máxima destruiçāo, é re-

72 PACHMUSS, Temira. The theme of vanity in Dostolevsikj works. The Slavic and East European Journal, Madison, 7(2):143-4, Summer 1963.

73 BAKHTINE, p. 173-4. 
alçado ainda mais pela pouca luz (força espiritual, criadora) que penetra pelas janelas embaciadas, com ar insidioso. A incidência de cor verde nas paredes sujas, nas ramagens do divā, na carteira usada, nas notas e até na libré alugada de Pietruchka, associada ao pó, nos fazem relacioná-la a um dos simbolismos desta cor ambitendente, que é a cor da vegetação mas também dos cadáveres. Considerando portanto a casa, a moradia de Goliádkin como identificada com seu corpo e espirito, vê-se a estreita relação entre ambos: Goliádkin fisicamente gasto e mentalmente em estado de desagreGação e seus aposentos empoeirados e sombrios.

A escada, já tão bem caracterizada por Grossman como local de cenas penosas, engloba idéias de ascensão e comunicaçāo entre os diversos níveis de verticalidade e, com sentido psicológico, ela figura a ruptura de nível que faz possível o passo de um mundo a outro, a comunicação entre céu, terra e inferno. Goliádkin sempre teve dificuldade em subir qualquer escada "que náo fosse a sua", como já mencionado, deste modo projetando a dificuldade de comunicação que ele tem para com os outros e a dificuldade de "subir" social e profissionalmente. Poder-se-ia até relacionar os très níveis céu, terra e inferno, ligados pela escada, com o quarto, a repartiçāo e a festa (inferno, terra e céu), no conto, o que equivaleria, na Menipéia, ao "fantástico", em que o herói é provocado e posto à prova (p. 160): o ambiente mesquinho de Goliádkin corresponderia a uma situação não desejada (inferno), a repartiçāo ao lugar onde ele atua (terra) e a festa seria a sublimação de todos seus desejos (céu).

Umbral: símbolo de transição, que separa dois mundos,' o local onde Goliádkin se encontra correntemente: à entrada da festa, do escritório, da casa do médico, do ministro. Goliádkin sempre espera do lado de fora. pois a transposição do umbral the traz humilhaçōes e dificuldades. $E$ assim como os dragōes e deidades guardam o umbral, os criados na casa de Olsuf : do ministro recusam a entrada de Goliádkin.

Muro: símbolo da impossibilidade de transir ao exterior; em forma de cerca, tem caráter de proteção. Goliádkin, a fim de observar os outros, procura sempre um lugar escondido, uma "muralha" que o proteja, sem que sẹ̣a visto. Assim também os cantos. que, para Bachelard sāo o mais sórdido dos refúgios, assegurando-nos um valor primordial do ser, a imobilidade. exercem papel importante na caracterizaçāo de Goliádkin, associados como estào aos buracos e à vontade de sumir de Goliádkin.

Portas e espelhos: Goliádkin diversas vezes vê o duplo "no meio da porta que supunha ser um espelho (p. 343 e 376)". O espelho, como símbolo Ja imaginação ou da consciência. capacitada para reproduzir reflexos do mundo visivel em sua realidade formal, é também visto com sentimento nmbivalente, como uma lâmina que reproduz as imagens $e$ as contém $e$ absorve. Além disso, é símbolo da multiplicidade da alma, de sua mobilidade r adaptação aos objetos que a visitam e retêm seu interesse. Como o eco, t' símbolo dos gêmeos - tese a antítese - e aparece em mitos como porta pela qual a alma se pode dissociar e "passar" ao outro lado. Os espelhos 
também são símbolos mágicos da memória inconsciente. Aplicando-se estes conceitos ao romance, vemos a pluri-significaçăo que o espelho adquire: no quarto de Goliádkin, refletindo seu aspecto físico e sua alma (ensonado, olhos semi-cerrados); no restaurante (cap. III), idem; na repartição, sente-se como alguém "sobre quem, por uma brincadeira de mau gosto, outros tivesses fixado um espelho", após a chegada do duplo (cap. VI); no restaurante, "na porta que dava para a sala vizinha que o nosso herói supunha ser um espeIho [...] estava um homem" (p. 343): o duplo ;em casa do ministro, "no meio da porta, que o senhor Goliádkin supusera ser um espelho, como já acontecera uma outra vez, apareccu o tal [...]" (p. 376). Esta ambigüidade espelho-porta, associando o sentido do primeiro com o do segundo, (porta como lugar de trânsito, umbral), evidenciam claramente a relação do espelho. como reflexo da alma - o duplo, e da porta, como lugar de passagem para o duplo; além da ambigüidade que os símbolos dão à narrativa. entre fantasia $e$ realidade.

Carruagem: assim como com a casa, há uma relação simbólica do carro com o ser humano; o condutor representa o "si mesmo" da psicologia jur guiana; o carro, o corpo e o pensamento relativo a coisas terrestres, enquanto os cavalos săo as forças vitais $e$ as rédeas, a inteligência e vontade. A carruagem representa para Goliádkin um meio de ascensão social. mas também é. como vimos, local de sua luta com o duplo, que o atira fora dela, "destronizando-o"; finalmente, é o meio de transporte que o leva ao manicômio. Haveria entāo, realmente, uma relaçāo entre a carruagem com o ser humano, pois, se no começo Goliádkin é o "dono" dela, após sua derrota pelo cuuplo na carruagem, Goliádkin passa a ser passageiro passivo. conduzido agora pelo médico Krestian Ivânovitch.

A ponte simboliza sempre o trespasse de um estado a outro, a mudança ou o desejo de mudança. O passo da ponte é a transição de um estado a outro, em diversos níveis, épocas da vida, estados do ser, mas a "outra margem", por definição, é a mortc. Este simbolismo coaduna-se perfeitamente com o uso que Dostoiévski dá à ponte no conto, local como é do primeiro encontro de Goliádkin com seu duplo, projetando o desejo de muúança, de aniquilamento, apoiado à amurada e mirando nas águas negras do rio. $\mathrm{O}$ abismo, local em que Goliádkin parece sempre que vai cair, ou sobre - qual se sente suspenso, pela sua dualidade como símbolo de profundidade e do inferior, se identifica com o país dos mortos, o que novamente está ıelacionado com o desejo de morrer, de desaparecer, de Goliádkin; "a terra se fende e o arrasta para a morte" (p. 316), "parece-lhe que cai num abismo", "sente-se suspenso sobre um abismo" (p. 316).

Eixo: lugar de confrontaçāo dos contrários. O estranho é o eixo em torno do qual Goliádkin gira, enquanto o movimento para trás após a passagem do duplo. cquivale, segundo Jung, ao inconsciente: Goliádkin é obrigado a se voltar, como que atraído pelo duplo, e olha "pelas costas" tal pessoa. Mais tarde corre a toda velocidade, "sem se voltar" (p. 316) mas já é tarde, pois a transmutaçāo já se deu. 


\section{II.2.2 No tempo cronológico:}

Assim como as horas marcadas servem para contrastar o caos da realidade de Goliádkin com a regularidade do passar do tempo, esta preocupação de Dostoiévski em relatar o tempo em minutos, horas e dias também poderia ser relacionada com o simbolismo das horas. Assim, pois, a meia noite, hora de encontro com o duplo, seria o símbolo da roda ou do cırculo ,ligado ao espaço e ao tempo. A noite, como princípio passivo e do inconsciente, c um símbolo dual e ambivalente, pelo seu estado prévio ao freparar o dia. e seu sentido de fertilidade. virtualidade e semente: é ela que vê nascer o duplo, e vê morrer Goliádkin, por ter o mesmo sentido do negro $c$ da morte.

Contrastando com o simbolismo da meia noite, as oito horas da manhă, horário habitual de o senhor Goliádkin levantar, expressariam as forças cósmicas, engendrando as ocasiōes de açāo humana. O oito entāo, como simbolo de generaçāo, equivaleria ao momento em que Goliádkin age realmente, em que se sente disposto a enfrentar a realidade.

\subsubsection{Nos elementos:}

A fúria dos elementos que se abate sobre Goliádkin, na tempestuosa - fatídica noite de seu primeiro encontro com o duplo, além de revelar o cstado de ânimo de Goliádkin e imitar a perseguiçāo de seus "inimigos". ainda poderia ser examinada sob seu aspecto simbólico.

Já a estaçāo outonal, associada com o triunfo da escuridão e dissoluçāo, fase do pôr-do-sol e da morte, mais a escuridāo da noite (símbolo da inversão vida-morte, apariçāo-desapariçāo, como também da oposiçāo de dois munclos, do negativo-positivo), concorrem para que a força dos elementos seja ainda mais evidenciada, na cena mencionada. A chuva com seu sentido de fertilização; publicação, a neve, relacionada com o caído do céu, como sublimaçāo da terra. o vento, de poder fecundador e renovador da vida, a agua (morte e dissolução mas também renascimento e nova circulaçāo), têm todos aquí uma conotação negativa, associados como estão com os males de novembro, com doenças e frio. "batendo e chacoteando o rosto de Goljádkin como agulhas", o vento soprando nas ruas desertas e erguendo a água negra do rio. A bruma, fusão da ảgua e do ar, alia-se aos elementos, fazendo com que Goliádkin nāo enxergue dois passos à sua frente. A neve o cobre inteiro, ele a sacode, mas nāo seus sentimentos de amargura: igualmente, sua situação é sem perspectiva de melhora, assim como o ar "úmido e enevoado". E o rio sobre o qual Goliádkin se debruça, símbolo ambivalente de fcrtilidade e do transcurso irreversível, levando ao abandono e ao esquecimento, está prestes a inundar, com seu sentido de morte e diluiçāo. A tempestade, criadora como tudo que vem do céu, também tem aquí uma cono- 
tação negativa, de acordo como está com os inimigos de Goliádkin, "para um dia e noite de amargura".

Finalmente a lama, mistura de dois elementos dos quais um é sempre - ativo, simbolizaria uma luta entre a água dissolvente e a terra absorvente, mistura de tudo que teve forma e a perdeu, segundo Bachelard.75 A lama cobre "os sapatos, as calças, ou antes, todo o corpo do lado esquerdo" (p. 370) de Goliádkin, cuja roupa ainda estava rasgada, em conseqüência da queda que levara da carruagem em que lutara com o duplo: como a neve que o cobria na noite de seu encontro com o duplo, a lama, encarada como mistura de tudo que teve forma e a perdeu ((predominância do elemento água), simbolizaria a dissolução da personalidade de Goliádkin, enquanto que, encarada como predominância do elemento terra, seria a desagregação na argila original, da poeira que fomos e à qual retornamos, isto é, fisicamente c: senhor Goliádkin também morre, ao ser afastado da sociedade.

\section{II.2.4 Na pessoa e no traje de Golladkin:}

Além do relacionamento de diversos símbolos com a carnavalização, tencho portanto uma conotação paródica, ainda poderíamos examinar alguns aspectos que de certa forma enriqueceriam o sentido total da personagem.

$O$ fato de Goliádkin ir descalço à janela de seu quarto, além de gesto carnavalesco, tem uma conotação simbólica com o pé como símbolo da alma, por ser o suporte do corpo; também o pé, o sapato e a pegada têm um significado funerário - o moribundo "vai embora". Por outro lado, as vistosas botas novas que Goliádkin calça e posteriormente perde na tempestade sāo, como calçado, signo de liberdade entre os antigos: os escravos iam de pés nús. E realmente, foi após o duplo usurpá-lo que Goliádkin perde suas galochas e torna-se um "escravo". Natália Nunes também se refere ao calçado, 76 dizendo que "este pormenor de preocupação com o calçado, com as botas, com as solas das botas [...] tem até uma tonalidade obsessiva em Dostoiévski".

Goliádkin é corpulento, calvo (simbolo da esterilidade do ancião), e míope (os olhos expressam a normaiidade física e seu equivalente espiritual: portanto, o esfacelamento da personalidade de Goliádkin se refletiria até em seu aspecto físico), cujos olhos cinzas simbolizariam o processo de desassimilação e de assimilação (simbolismo do branco-negro). A máscara que ele afirma não usar, está relacionada com todas as transformaçōes, que têm algo de misterioso e vergonhoso, porque o ambíguo se produz no momento em que algo se modifica para ser outra coisa, mas ainda continua sendo o

74 Todas as referēncias a simbolismo foram achadas no Diccionário de simbolos, de Juan Eduardo CIRLOT, já mencionado.

75 BACHELARD, Gaston. Ia terte et les revêries de la volonte. Paris, J. Corti, 1948. p. 130 .

is DOSTOIEVSKI, Obra completa, v. 1, p. 132. 
que era. Daí a máscara, porque as metamorfoses têm que ocultar seu caráter mágico, tanto na máscara teatral com na religiosa. Além disso, a máscara constitui uma imagem e tem outro sentido simbólico que deriva do figurado de tal mancira. Goliádkin odeia máscaras (transformaçōes), mas ele mesmo gostaria de ser diferente. Sempre repete: “[...] quando a máscara de certas pessoas tiver caído e tudo seja visível..." (p. 295-6), "nāo me agrada usar máscara [...]" (p. 294). "há homens que nảo gostam de rodeios e que só pōem máscara para ir aos bailes". (p. 301). Assim como a dança (imagem corporizada de um processo, pois toda dança é pantomima de metamorfose e por isso requcr a máscara, convertendo o bailarino em deus, em demônio) que Goliádkin nāo consegue realizar, pois tropeça e cai, a máscara projetaria a ironia de uma metamorfose a que Goliádkin aspira - a ascensão social - mas que ao mesmo tempo repele e nāo sabe usar. Mas a metamorfose ocorre, sem cle o descjar: sua duplicaçāo em Goliádkin II, que realiza seu sonho de ascensão às avessas, isto é. destronizando Goliádkin. A dança natusalmente está ligada ao simbolismo da festa, como ambiente feérico, sobrenatural, em contraposição à realidade de Goliádkin, como já mencionado.

Os objetos comprados por Goliádkin, e os apenas escolhidos, juntamente com os rublos que guarda tāo cuidadosamente, são simbolos não apenas de abundância. como parte da carnavalização, mas também como moedas, os rublos teriam certo sentido talismânico, como expressão de poder. E "uma quantia interessante! [...] Uma importância destas pode levar uma pessoa muito longe" (p. 288), diz Goliádkin, alegremente.

O samovar, como "imagem-objeto que penetra na açāo", segundo Grossman 77 aparece descrito nāo só animicamente no primeiro capitulo78 lembrando pela sua descrição o pulsar desordenado de um coração, como é dramatizado novamente na cena final, em que o coração de Goliádkin é descrito com as mesmas palavras:

O senhor Goliádkin sentia uma dor estranha no coraçāo; o sangue parecia ferver-lhe na cabeça, que estalava. Sentia-se abafar, teria querido desabotoar-se, por o peito ao léu, cobri-lo de neve, inundá-lo de água fria (p. 388).

o cachimbo, que Goliádkin fuma com o duplo, como imagem do fogo. seria um fator de unificação, pois realmente é o instante em que ambos travam amizade, se bem que por pouco tempo: é o "cachimbo da paz".

o candelabro, que Goliádkin carrega ao examinar o duplo dormindo, como a lâmpada, é símbolo de luz espiritual; na cena final do conto, em casa de Olsuf Ivânovitch é o duplo que assumiu este papel e ilumina o caminho para Goliádkin e o médico.

Poderíamos ainda incluir aqui, como extensāo, o simbolismo da sombra em referência ao duplo, como sendo o duplo negativo do corpo; o primitivo

77 GROSSMAN, Dostoievski artista, p. 155.

$78 \mathrm{Cf}$. p. 14. 
considera sua sombra ou sua imagem na água ou num espelho como sua alma ou uma parte vital de si mesmo: "Na sua frente, uns vinte passos, a silhueta negra dum homem avançava rapidamente" (p. 315). Esta "silhueta negra" que Goliádkin vê, é sua própria sombra, é o seu duplo. E, em relaৎão ao duplo, quando este mostra seu "riso trocista", mostra "os dentes [...] saltitando como um sorriso que era uma saudação a todos" (p. 359): a sorriso transforma-se por meio dos "dentes", em arma de ataque e ex-

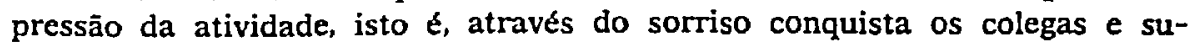
periores e ao mesmo tempo irrita a Goliádkin, "atacando-o" com sua troça.

\section{II.2.5 No "duplo":}

o Simbolismo do número dols, como eco, reflexo, conflito, contra-posição, quando as forças sāo iguais, relacinado também com o simbolismo cos gêmeos e do duplo, percorre toda a narrativa. Praticamente todos os objetos referidos são duplos: Pietruchka vê dois Goliádkin, Goliádkin pede dois jantares. Goliádkin e duplo vão viver "juntos como peixes na água. como irmãos", Goliádkin experimenta duas sensaçōes: feliz e cansado; a cama do duplo são duas cadeiras grandes; o duplo lhe dá dois piparotes na cara; Goliádkin acha que Pietruchka vai levar duas horas para entregar a carta; ao acordar Goliádkin ouve o relógio bater duas pancadas; Vakramáiev na carta pede a Goliádkin lhe pagar dois rublos que lhe deve; Sua Excelència passa duas vezes pela seção; a casa do diretor é a dois passos dalí; o duplo aperta desdenhosamente dois dedos da mão de Goliádkin; o duplo quer falar a Goliádkin como se fossem dois camaradas; Goliádkin paga as duas despesas à dona do restaurante; derruba duas vendedeiras na ponte; vai a uma taberna a dois passos dali; Klara se entregar à proteçāo de Goliádkin à duas horas; Goliádkin passa duas soras no pátio de Olsuf Ivânovitch; recua dois passos quando derruba o remédio; pōe as māos no espaldar de duas cadeiras; Goliádkin passa por duas filas de observadores, etc.

Os gêmeos, símbolo da natureza em sua necessidade de transformação binária e contraditória, são representados pelo branco e negro. Goliádkin e o duplo são "gêmeos como duas gotas de água", e o sentido simbólico mais geral dos gêmeos é que um significa a porçāo eterna do homem, a alma, enquanto o outro é a porçāo mortal. Mas como também simbolizam os princípios contrapostos do bem e dó mal (o que é corroborado por Henri Troyat). cles aparecem igualmente como inimigos mortais. A duplicldade ("minha tia, antes de morrer, deu para ver as coisas em duplo" diz Antônovitch a Goliádkin) a multiplicidade do mesmo, como imagem de ruptura, dissociaçāo. separaçāo, é símbolo característico patológico: lembramo-nos como Go. liádkin sonha com muitos Goliddkini e que na cena final vê "uma multidāo numerosa de Goliádkini absolutamente iguais" (p. 386) na casa de Olsuf Ivánovitch. No excepcional, sonha-se que uma multidão de objetos ou pessoas apresentam os mesmos traços, 'o que alude à secreta e terrivel unidade de 
tudo. A angústia que acompanha este simbolo provém da psicologia da "repetiçāo" e do fato de que neste mundo a diversificação parece ser lei. A duplicação numericamente corresponde ao número dois, e portanto, ao conflito; e o dualismo, como todo sistema binário, apresenta a inimizade dos dois princípios em luta.

\section{II.2.6 Na fábula:}

A titulo de experiência. poderíamos ainda encaixar parte do simbolismo do romance num contexto de feitiçaria, de sortilégio, de magia. Assim, o médico seria o "confessor", o feiticeiro, que, como o gigante e o bruxo, personificam o pai terrível (é o aspecto do médico, desde o início, com seus olhos brilhantes que, na cena final, se transformam em "dois olhos brilhantes como duas brasas" refletindo "uma alegria diabólica e de mau pressárigio"), mas que no final se ambiguiiza com o duplo. Assim, também o remédio que o médico lhe receitara - a poção mágica que de certo modo evitaria o sacrifício de Goliádkin, mas este a derrama - e sua cor vermelha, se identificam ao sangue: símbolo perfeito do sacrifício, pois o dom aplaca as potências e aparta os castigos maiores. E "o liquido repugnante e vermelho escuro" que aparece sob seus olhos, quando o frasco cai e quebra. Outros sintomas de sacrificio seriam o sangue que Goliádkin, ao estar apoiado na amurada do cais, parecia quase ter começado a pôr pelo nariz, o dedo da māo direita que Goliádkin cederia de bom grado a um mágico, para fazer desaparecer seu duplo, a ferida (o furúnculo), com igual significado de sangue, que Goliádkin prognostica que possa lhe aparecer, na primeira cena.

Portanto, Goliádkin tendo obtido a poçāo mágica mas nāo fazendo uso dela, para se salvar, c sacrificado, o duplo "renascendo" em seu lugar. Esta interpretaçāo poderia ser corroborada pelo elevado número de vezes em que Goliádkin se refere à feitiçaria, à feiticeira maldita, a veneno, a mágico, como sc ele mesmo acreditasse estar sendo vítima de um sortilégio.

- Vê-se desta maneira como Dostoiévski, inconscientemente é evidente - como também a Menipéia nāo estava presente na memória subjetiva dele - conseguiu formar de certo modo um todo simbólico relacionado com duplicidade, desagregação, luta de contrários e dissoluçāo, através dos diferentes elementos da narrativa. integrando-os no contexto da fábula, assim como também a forma fragmentada da narrativa é um reflexo do mesmo conteúdo bifurcado.

Mas, para concluir, é necessário ainda tratarmos dos subtítulos do romance a fim de articularmos todos os elementos levantados.

\section{CONCLUSAO \\ O Duplo, imitação, confissão ou poema petersburguense?}

Como já vimos, os contemporâneos de Dostoievski viram em O Duplo uma imitaçủo de Gogol, além de considerar a obra como "estranha". O es- 
critor, por sua vez, dá-lhe o sub-título "Poema Petersburguense", e mais tarde a chama de "confissāo". Como poderemos classificá-la, pois, dentro do contexto de duplicidade, de fragmentação, examinado?

Conforme Yuri Tynianov, 79 falando-se de "tradição literária" imaginamos uma linha reta, mas trata-se antes de uma partida, de uma repulsão de um determinado ponto, portanto de uma luta em relação a um representante mais jovem ligado ao mais velho. Para Tynianov, Dostoievski parte ostensivamente de Gogol, mas devemos falar antes de estilização e paródia do que de imitação. Observa Tynianov também que na época de Dostoievski sć poucos criticos falavam em luta, em relação a ambos, pois a maioria nāo a havia ainda percebido, como também nāo perceberam, conforme citado. a nova lógica de motivação que contradizia a tradição da novela social vigente na época.

Por outro lado, O Duplo também nāo é apenas imitaçāo mais "confissāo", como afirma Troyat: 80

Esta longa narrativa Dostoievski intitulou-a "poema". Mais tarde, falará dela como "confissāo". E era na verdade uma confissāo, que os seus contemporâneos nāo souberam discernir sob a anedota hoffmannesca [...] Esse desgraçado que entra no salāo de André Filípovitch [...] não será o próprio autor no mais denso dos ccnáculos literários?

E nāo é Dostoievski que pensamos quando Goliádkine se escapa da casa iluminada [...]? E o outro, o falso Goliadkine, o "usurpador", como Dostoievski o designa? E ainda Dostoievski. O dos êxitos brilhantes, o mundano..."

Entretanto, como afirma Bakhtine, 81 Dostoievski via em 0 Duplo uma "confissão" nāo no sentido pcssoal, evidentemente: "Le Double est la première confession dramatisée dans l'oeuvre de Dostoievski". Esta afirmação é corroborada, num contexto mais amplo, por Antonio Cândido, 82 para quem "o princípio que regc o aproveitamento do real é o da modificação, seja por acréscimo, seja por deformaçāo de pequenas sementes sugestivas. O romancista é incapaz de reproduzir a vida, seja na singularidade dos indivíduos, seja na coletividade dos grupos". As personagens "nāo correspondem a pessoas vivas, mas nascem delas".

Já para Grossman. Dostoievski tem como base do seu método criador o princípio tríplice da nova epopéia: o fundo realista completado com o desvendamento das tensões e dramas sociais $\mathrm{e}$ individuais, mais a luta interior $\mathrm{c}$ as meditaçōes de individuos levados ao desespero e condenados à destruição. 83

79 TYNJANOV, Jurij. Dostoevskij und Gogol; zur Theorie der Parodie. In: TEXTE der russischen Formalisten. Mtinchen, Fink, 1969. v. 1, p. 301.

80 TROYAT, p. 95 . Ver também p. 4.

81 BAKHTINE. p. 279.

82 A PERSONAGEM de ficção. Sāo Paulo, Perspectiva, 1972. 6. 67.

83 GROSSMAN, Dostolevski artista, p. 13-4. 
E esta complexa estrutura interior, fusão de epopéia com poesia e drama, faz com que Dostoievski defina scu gênero literário com o sub-título de "poema": 84 "O pocma está pronto e foi criado antes de tudo o mais, como sempre deve ocorrer com um romancista", diz o próprio Dostoievski. 85

Através de todas estas afirmaçōes, vê-se como é dificil realmente, che• gar a uma conclusāo definitiva para classificar o Duplo, levando em consideração nāo só os clementos auferidos por Dostoievski de toda uma tradição literária. desde as características da Menipéia e da carnavalizaçāo literária, "presente na memória objetiva do gênero que ele empregava", como mencionado, até uma "luta" mais aberta em relação ao seu antecessor direto, Gogol.

Os elementos "confessionais", por outro lado. também nāo podem deixar de ser considerados. se bem que "modificados". Detendo-nos um pouco mais no sub-titulo "Poema Petersburguense", poderiamos dizer que o próprio sub-título cria uma ambigüidade, um desdobramento em relaçāo ao título o Duplo, pois, na tentativa de unir epopéia com poesia e drama. Dostolevski está também mantendo uma multiplicidade de níveis, que por sua vez confirma e projeta a polifonia e multivocidade do todo. Poderíamos ainda acrescentar a este todo uma intenção paródica, como o próprio autor ¿liz, na narrativa "Seria pelo jantar que haveria de começar o meu poema" (p. 305), o que torna 0 Duplo ainda mais "multivocal e discordante", segundo Bakhtine 86

Acreditamos que no elemento paródico possa ser encontrado um dos pontos de articulação de todos os elementos levantados neste contexto de cuplicidade. porque a obra além de ser tudo isto, também é critica social ao pequeno funcionário de São Petersburgo, que num mundo caótico em que a ambição profissional e a lisonja tomaram o lugar da primitiva honestidade e simplicidade, não consegue acompanhar esta mudança e sente o esfacelamento de sua personalidade. Isto tudo é apresentado então, num contexto paródico, pois se a obra é um poema pela multiplicidade de níveis e pela polifonia de vozes e visões, dentro dessas vozes ouve-se o trágico com acentos cômicos, e o cômico com reflexos trágicos; nāo há cena, nāo há gesto cu pensamento em 0 Duplo, em que o monológico não esteja fragmentado, $\mathrm{cm}$ que não penetre a carnavalização, transformando assim. como diz Tynianov, a paródia de uma tragédia $\mathrm{em}$ uma comédia, através do dualismo que impregna toda a narrativa. tornando pois inseparáveis forma e conteúdo. Todos os elementos levantados conseguem se articular dentro deste contexto de duplicidade, de fragmentação, desde o título da obra, através dos diversos níveis abordados da narrativa, até sua conclusão.

84 GROSSMAN, Dostoievski artista, p. 22.

85 Toid., p. 23.

S6 BAKHTINE, p. 294. 
Tentamos pois, fazer uma leitura de 0 Duplo, em que demonstramos como não podemos considerar a obra como "fracassada", pois a riqueza de material explorado por Dostoievski, aliado à sua visão particular e profunda da natureza humana, transformam $O$ Duplo realmente em ponto de partida para um estudo mais profundo da obra desse escritor, que captou tăo dramaticamente o mundo fragmentado, caótico e polifônico que nos rodeia.

\section{REFERENGIAS BIBLIOGRAFICAS}

BACHELARD, Gaston. La terre et les revêrics de la volonté. Paris, J. Cortt, 1948. $407 \mathrm{p}$.

BAKHTINE, Mikhail. La poetique de Dostolevskj. Paris, Seuil, $1970.347 \mathrm{p}$.

CIRLOT, Juan Eduardo. Diccionário de símbolos. Barcelona Labor, 1969. 495 p.

DOSTOIEVSKI, Fiodor M. Obra completa, Rio de Janeiro, Agullar, 1963. v. 1.

-. Obras completas, Madrid, Aguilar, 1953. v. 1.

DUCROT, J. \& TODOROV, T. Dictionnaire encyclopédique des sciences du langage. Paris, Seull, $1972.470 \mathrm{p}$.

Grossman Léonide. Dostoievski. Moscou, Ed. du Progrès, 1970. 539 p.

- Dostolevski artista. Rio de Janeiro, Civilizaçăo Brasileira, 1967. 274 p.

FAUSER, Arnold. História social da literatura e da arte. São Paulo, Mestre Jou, 1972. v. 2.

hOFmanN, M. Histoire de la littérature russe. Paris, Payot, 1934, 694 p.

MOISES, Massaud. Guia prático de análise litexária. Sāo Paulo, Cultrix, 1970. 284 p.

PACHMUSS, Temira. The theme og vanity in Dostoevsky's works. The Slavic and East European Journal, Madison, 7(2):142-59, Summer 1963.

A Personagem de ficção. Sāo Paulo, Perspectiva, 1972. 125 p.

SAPIR, Edward. Lingüística como ciência Rio de Janeiro, Acadêmica, 1969. 203 p. TEXTE der russischen Formalisten. München, Fink, 1969. v. 1.

TROYAT, Henri. A vida de Dostoievski. Lisboa Estúdios Cor, 1958. 471 p.

WASIOLEK, Edward, Dostoevsky, the major fiction. Cambridge, MTT Press, 1964. $248 \mathrm{p}$.

WELLEK, René ed. Dostoevsky; a collection of critical essays. Englewood-Cliffs, N.J., Prentice Hall, 1962. 180 p.

- Konfrontationen. Verglcichende Studien zur Romantik. Frankefurt, Suhrkamp, 1964. $184 \mathrm{p}$. 
RENAUX, S. Dosloiershi

\section{Resumo}

Esta análise de 0 Duplo de Dostoievski baseada em Mikhail Bakhtire e Leonid Grossman, procura mostrar com a duplicidade na forma deste romance corresponderia a uma duplicidade de conteúdo: assim, o duälismo entre sonho e realidade, a polifonia do foco narrativo, simbolismo, tempo, espaço e outros elementos, serviriam para projetar o desdobramento da personagem principal. Conclui-se com uma interpretaçāo que se coaduna com a visão polivalente que Dostoievski nos dá de sua c de nossa realidade.

\section{Summary}

This analysis of Dostoevsky's The Double is based on Mikhail Bakhtine and Leonid Grossman and it tries to show how the duplicity of form in this novel corresponds to a duplicity of subject matter: in this way, the duality between dream and reality, the polyphony of speech, symbolism, time, space and other elements, all help to project the double nature of the main character. We conclude with an interpretation that conforms to the polyvalent vision that Dostoevsky has given us of his and of our reality. 